أثر الفساد الإداري في السياحة: دراسة لتصور ات عينة من العاملين بالمناصب العليا بالثركات السياحية

\author{
أحمد محروس خضير
}

ملخص

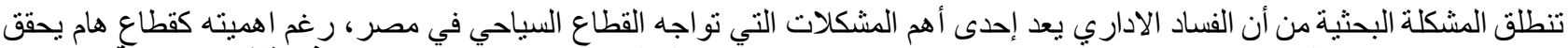

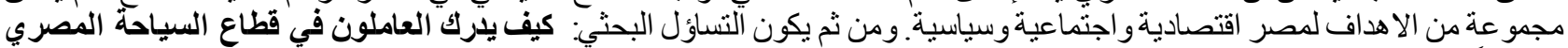

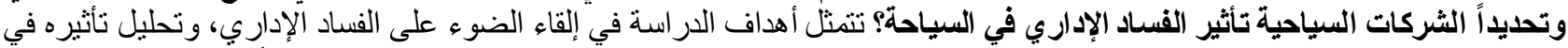

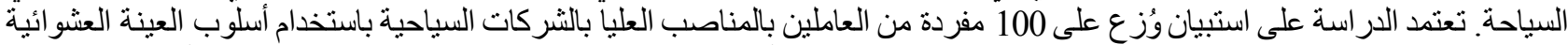

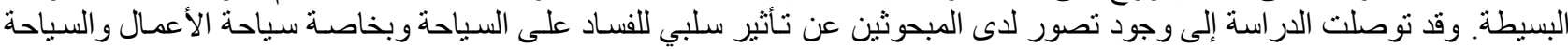

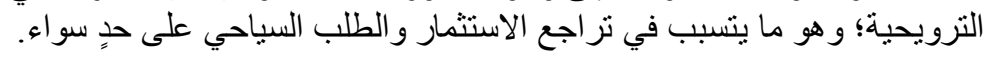

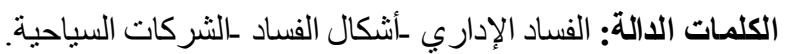

المقدمة

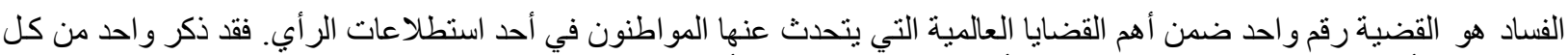

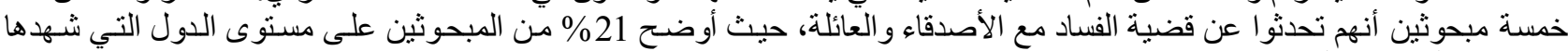

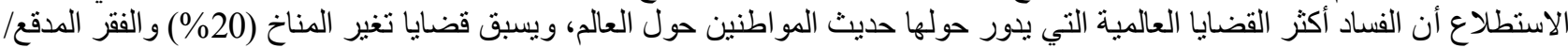

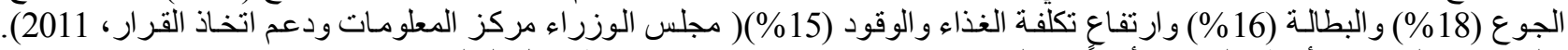

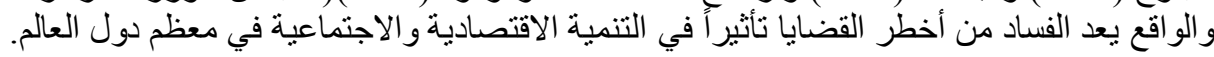

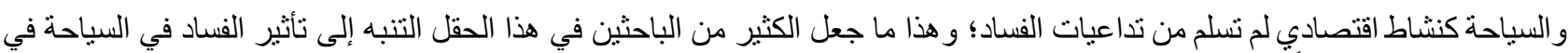

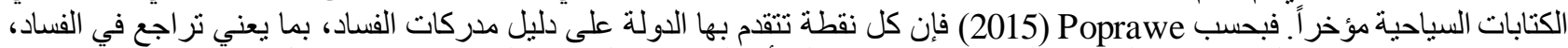

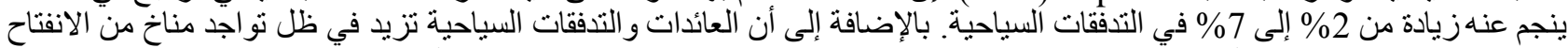

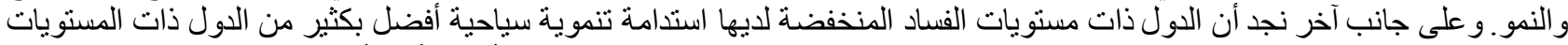

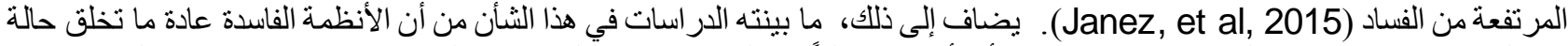

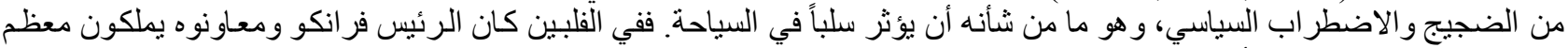

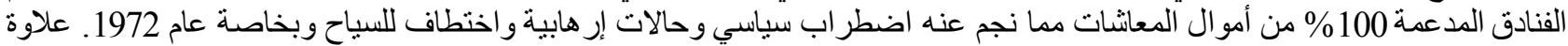

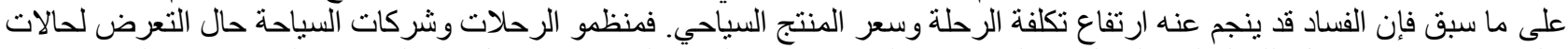

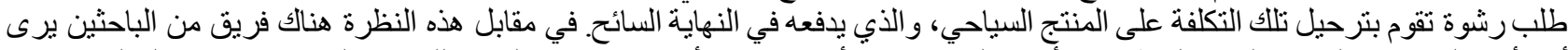

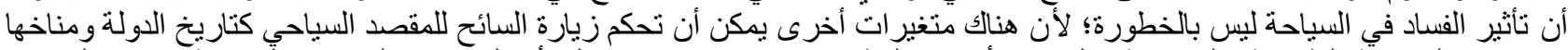

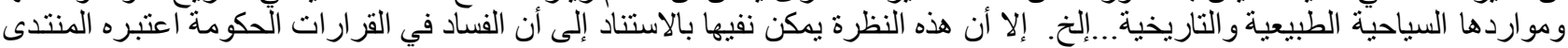

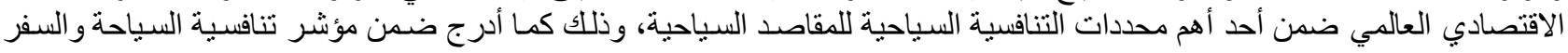

.WTTI

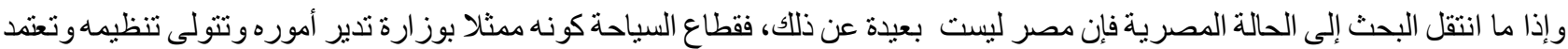

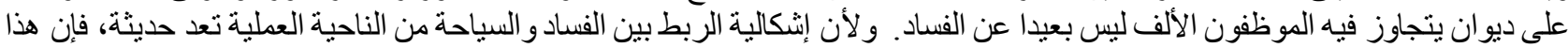

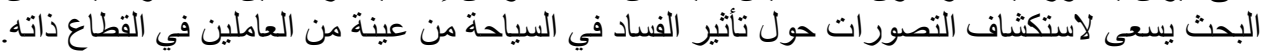

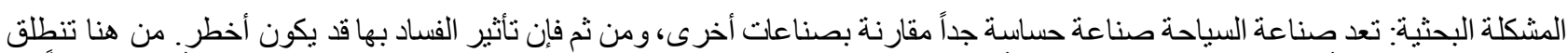

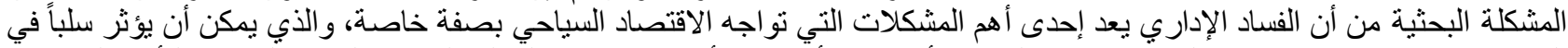

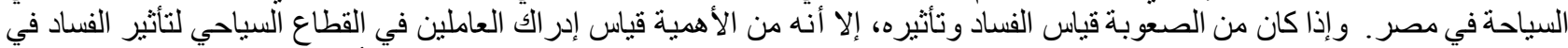

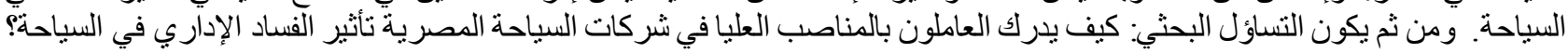

$$
\begin{aligned}
& \text { أهداف الدراسة: } \\
& \text { • • إلقاء الضوء على الفساد الإداري؛ } \\
& \text { • • استكثاف وتحليل الرؤى المختلفة لتأثير الفساد الإداري في السياحة؛ } \\
& \text { • دراسة تطبيقية لتصور ات عينة من العاملين بالمناسب العليا بشركات السياحة في مصر عن تأثير الفساد في السياحة في مصر. }
\end{aligned}
$$

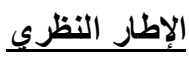

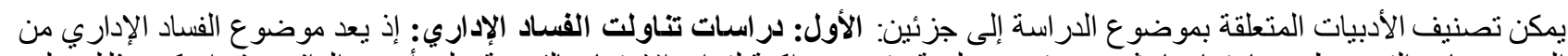

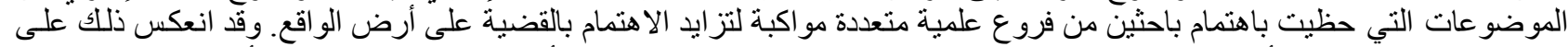

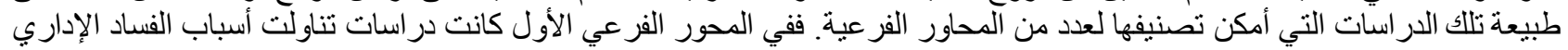




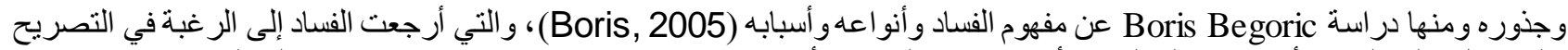

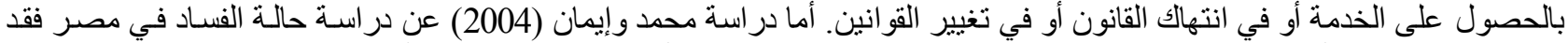

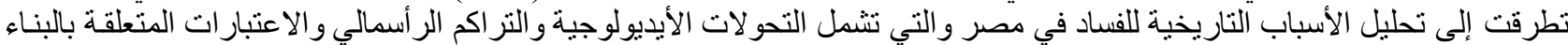

الطبقي.

ونأتي دراسة (khan, 2016) عن الفساد السياسي والإداري مع التطبيق على بنجلاديش، لتتناول المداخل المختلفة لنشر الفساد (مدخل

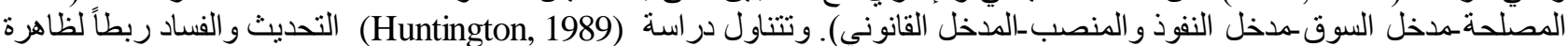

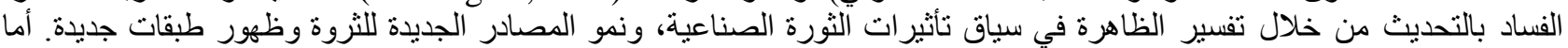

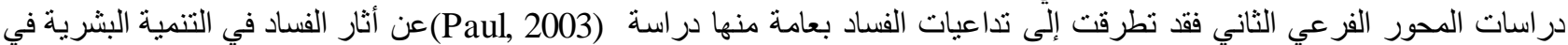

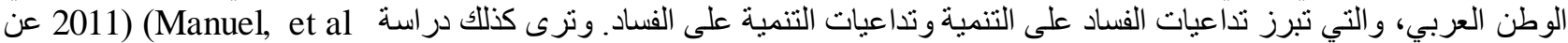

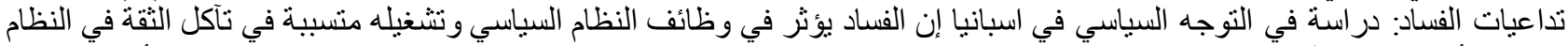

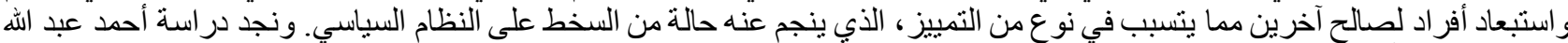

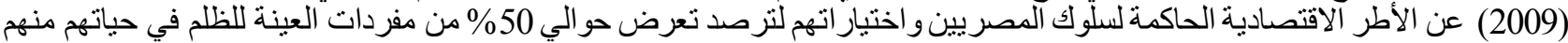
32.7 \%ان مصدر تعرضهم للظلم الحكومي.

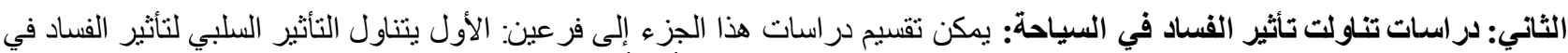

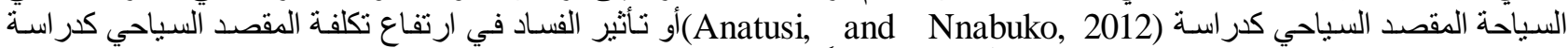

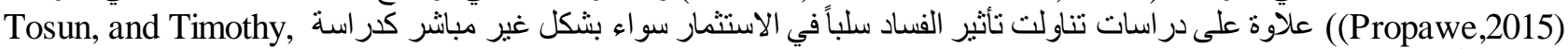

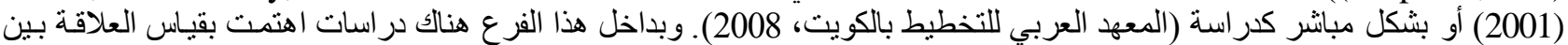

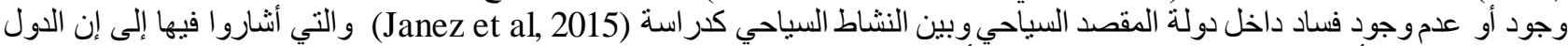

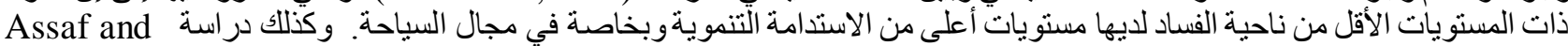

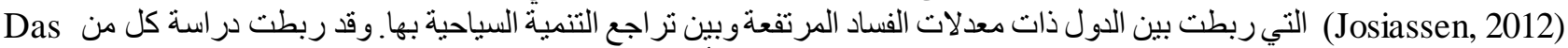

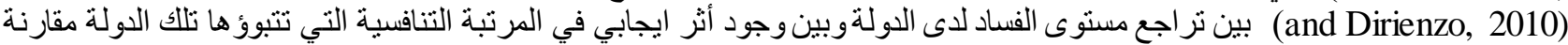

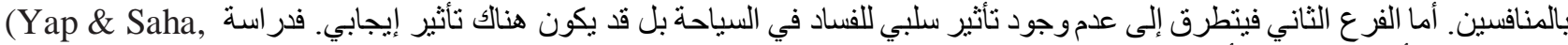

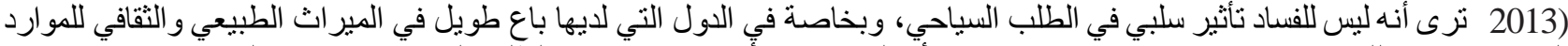

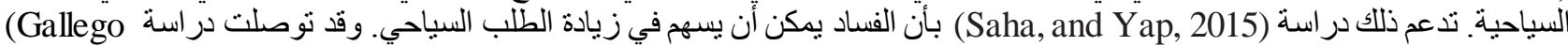
إلى وجود علاقة طردية بين معدل الفساد في دولة السائح ومدى تسأمحه مع ممارسات الفساد السياحي في دولة المقصد.

تعريف الفساد الإداري:

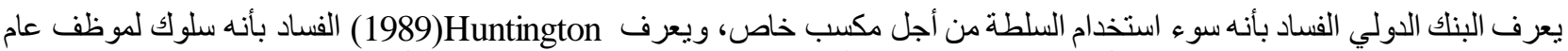

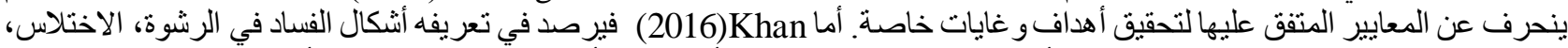

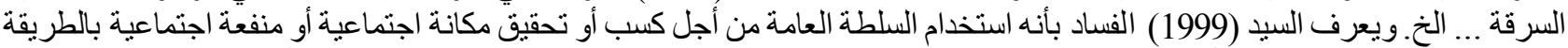

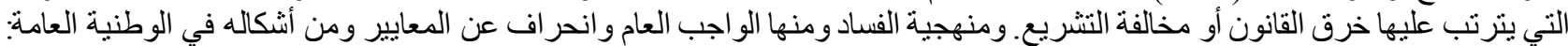

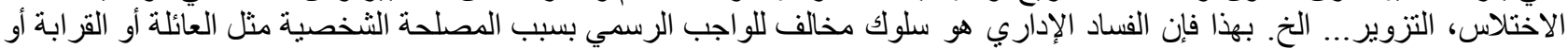

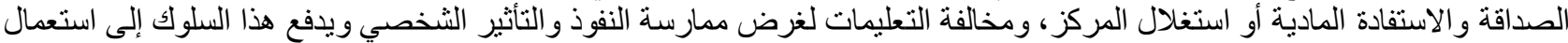

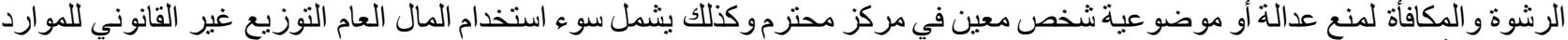

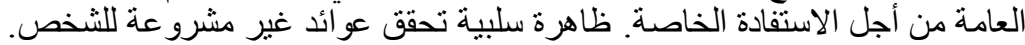

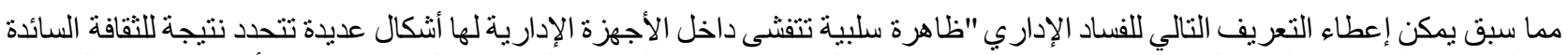

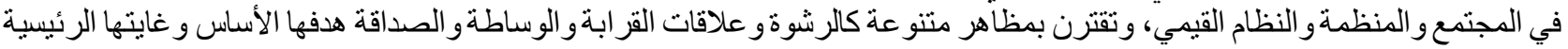

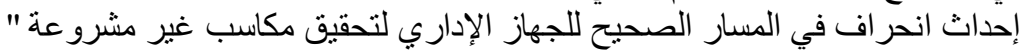

أنو اع الفساد الإداري

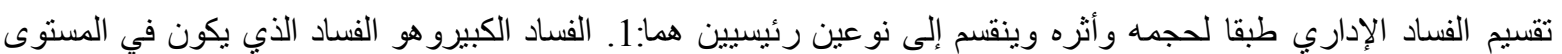

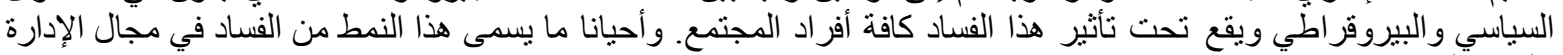

بالفساد ألثبكي.

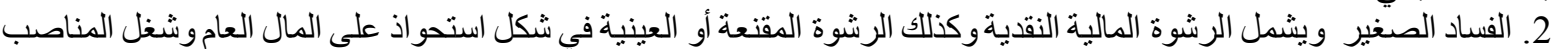

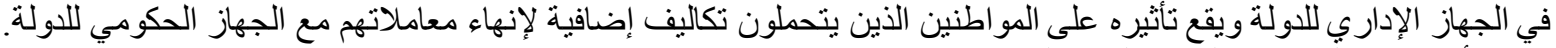
بسمى أيضا هذا النمط من الفساد بالفساد الفراد الفردي.

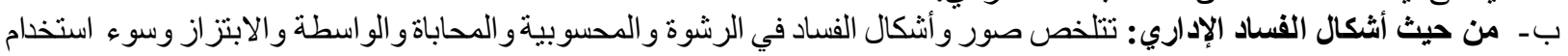
السلطة ونهب المال العام...إلخ.

تأثير الفساد الإداري في السياحة

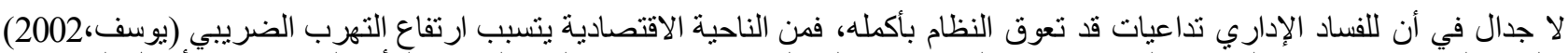

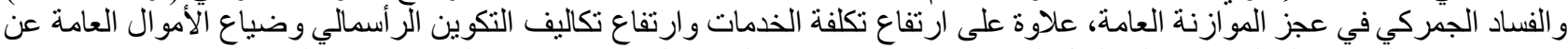

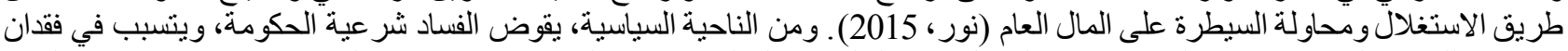

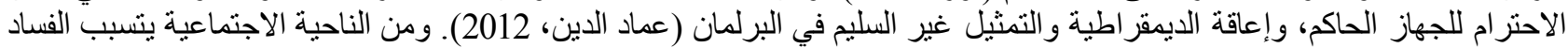


كذلك في اغتر اب المتعرضين لله وانعز الهم عن المجتمع، بل وقد يؤدي إلى إضعاف الثنعور بالانتماء للبلد، حيث يتسبب الفساد الإداري في

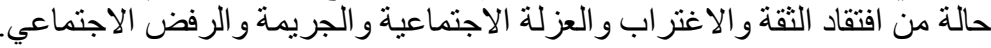

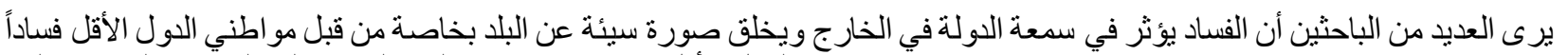

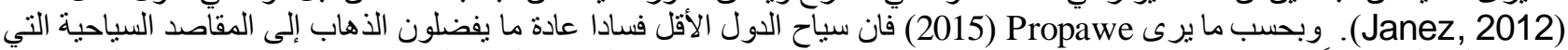

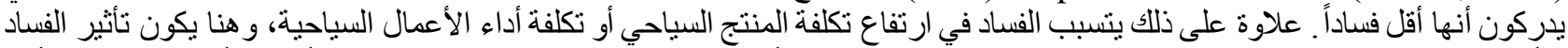

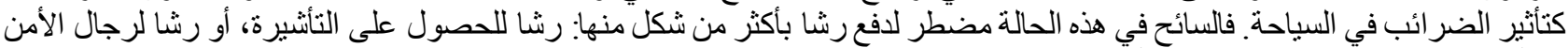

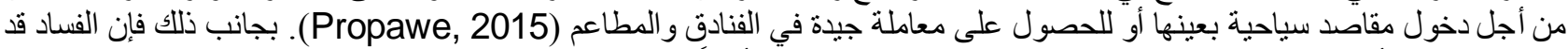

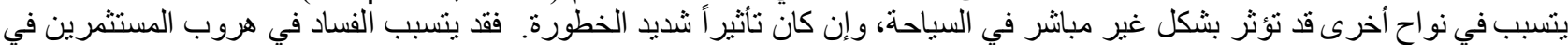

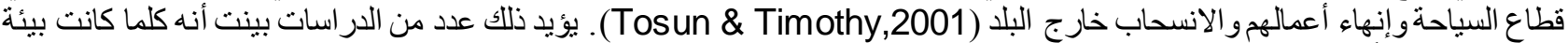

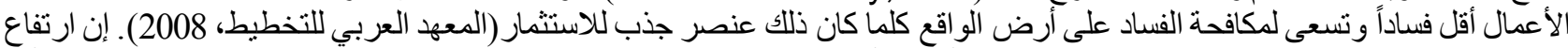

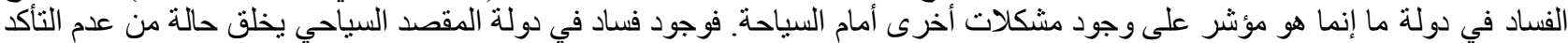

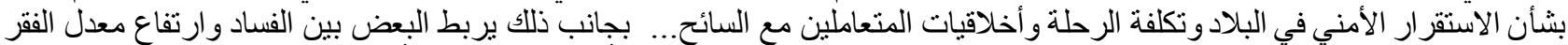

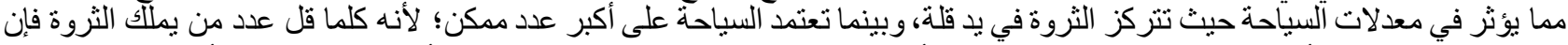

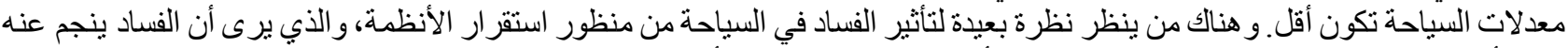

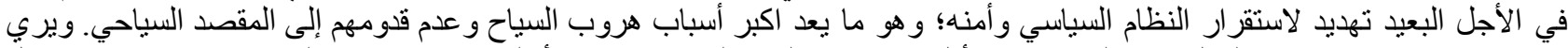

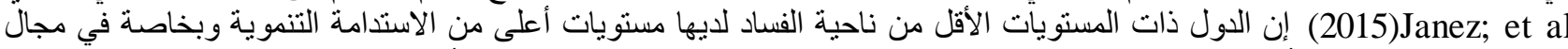

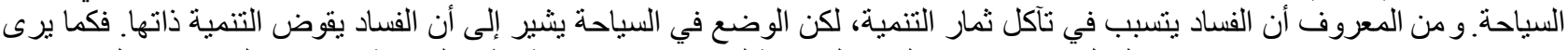
وجادئي Assaf an Josiassen

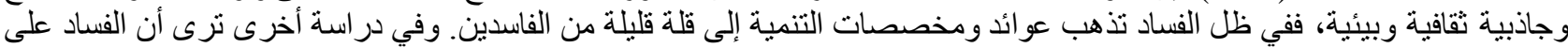

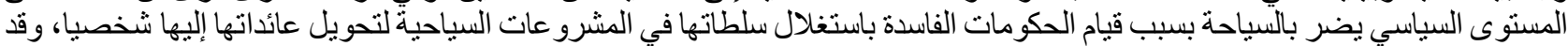

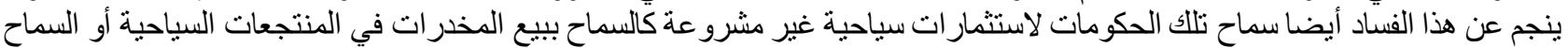

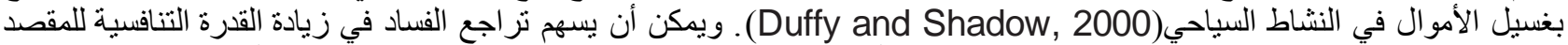

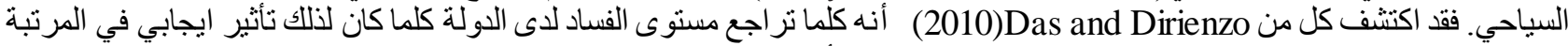

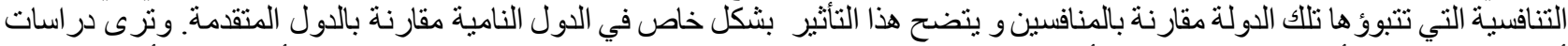

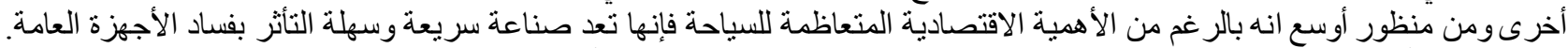

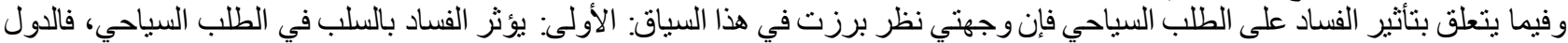

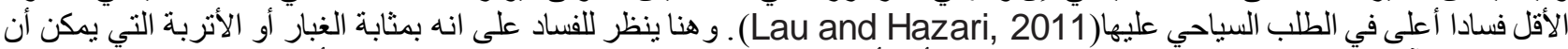

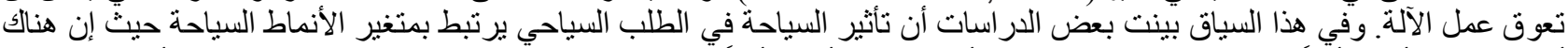

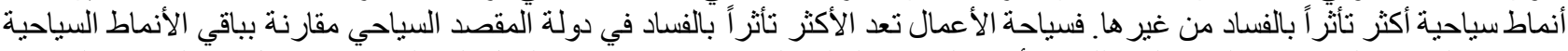

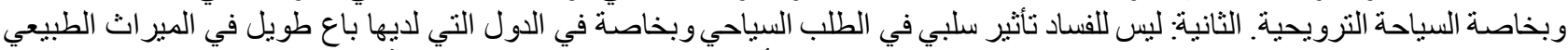

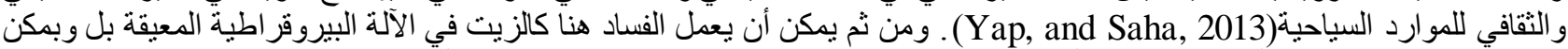

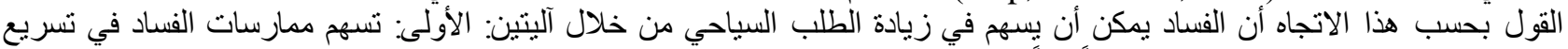

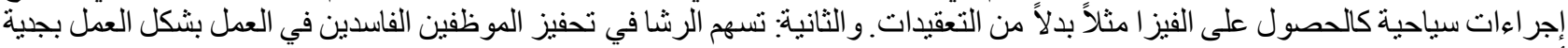

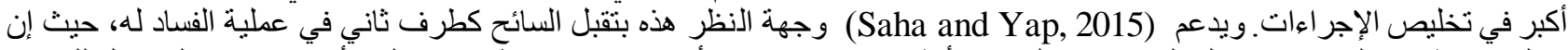

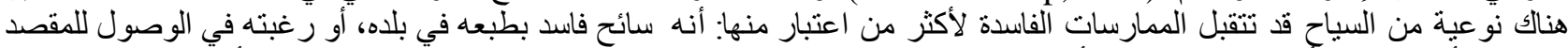

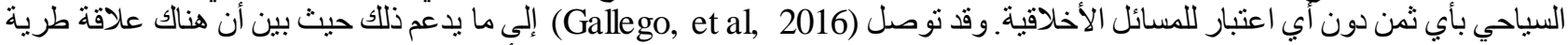

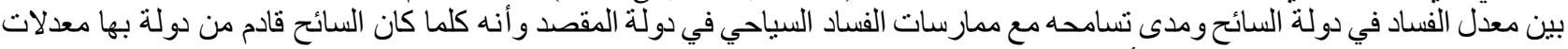

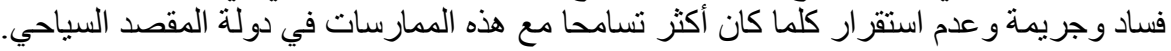

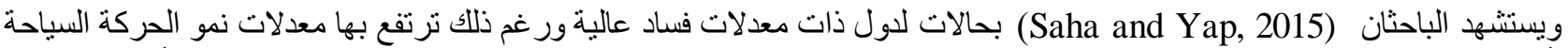

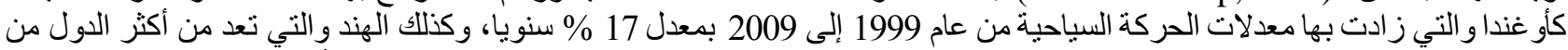

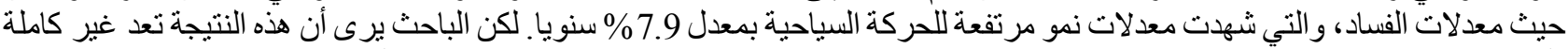

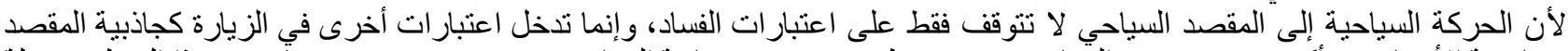

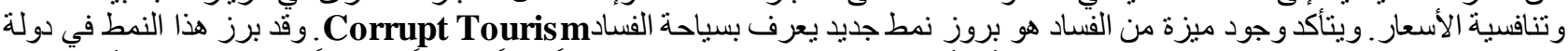

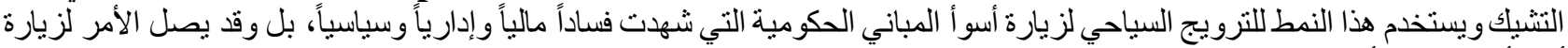

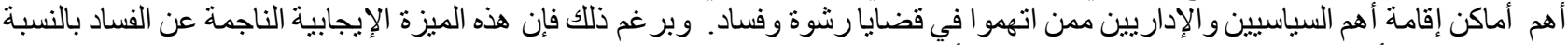

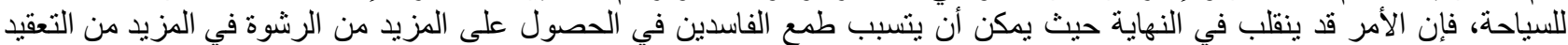

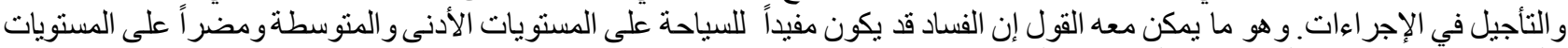

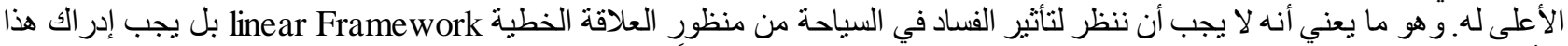

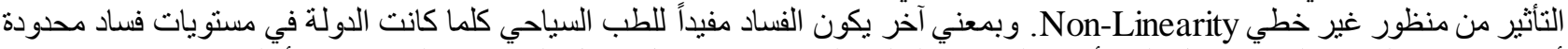

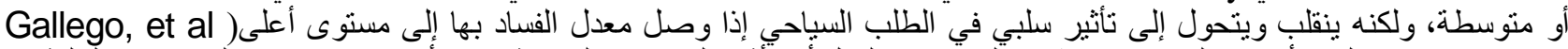

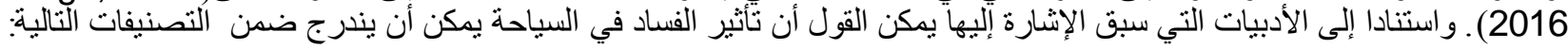




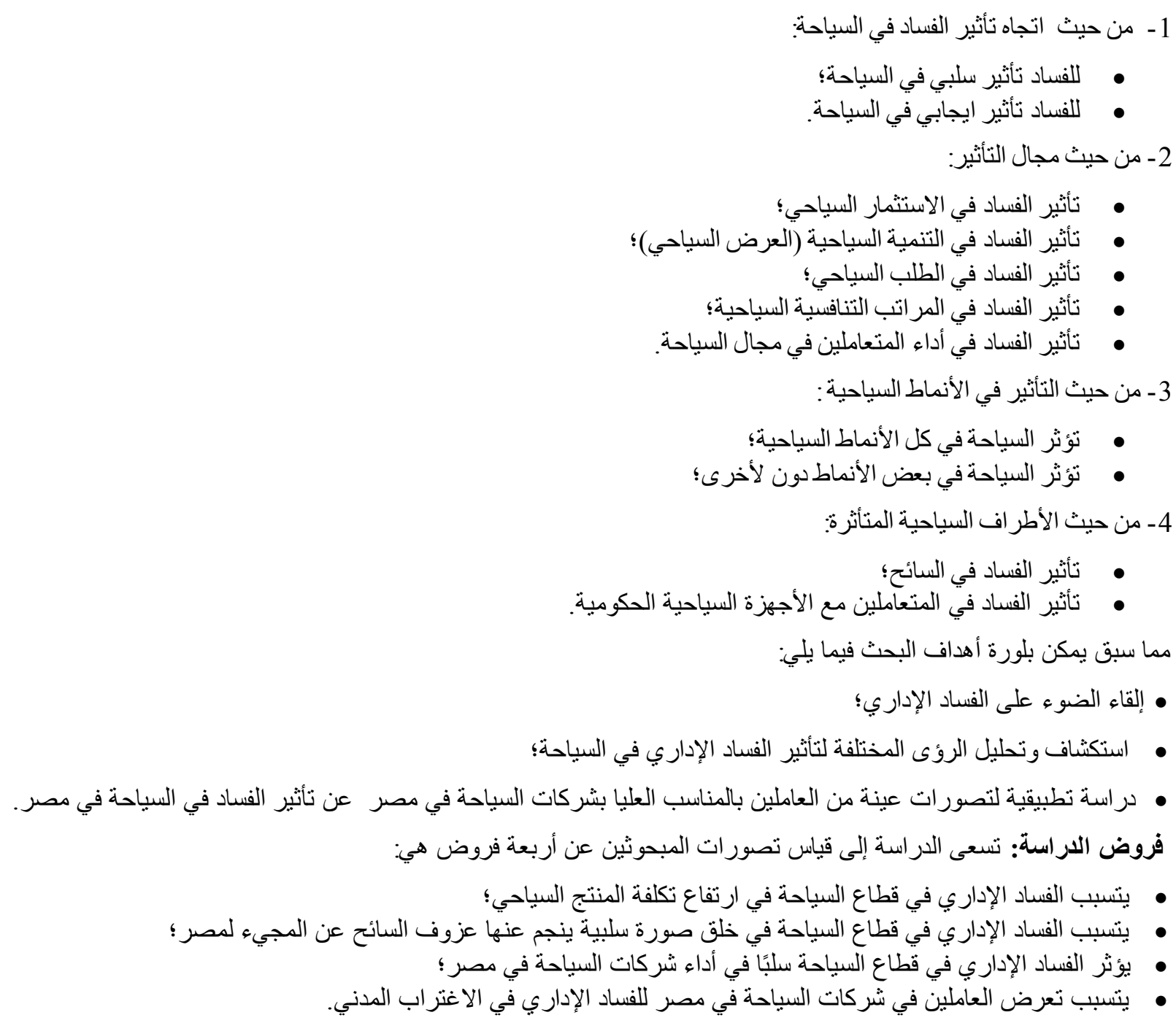

منهج الدراسة:

1- المنهج الاستكشافي الوصفي التحليلي: ويقوم على وصف ظاهرة الفساد الإداري في مصر من خلال رصد ما ما يحدث أو أو تحليل

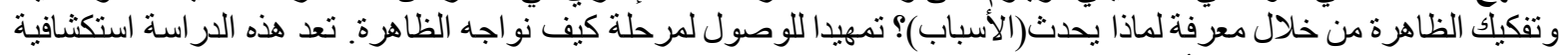

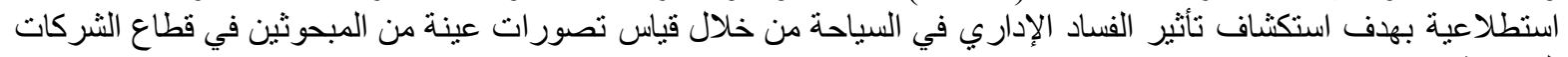
السياحية. 2- المنهج الاحصائي: من خلال اعتماد الأساليب الإحصائية كالجداول التكرارية والانحر اف المعياري علاوة على اعتماد معامل

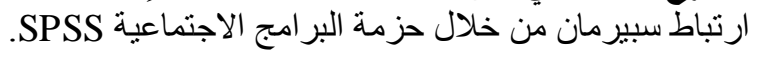

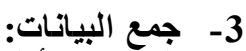

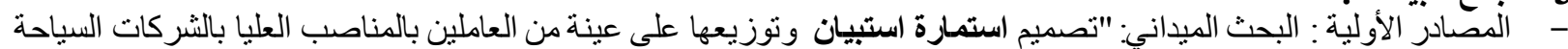

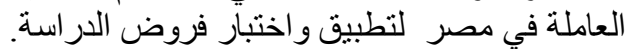

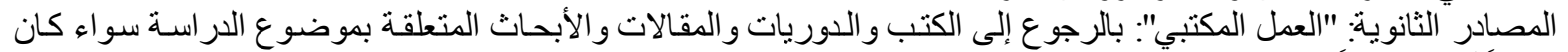
مكتبياً أو إلكترونياً.

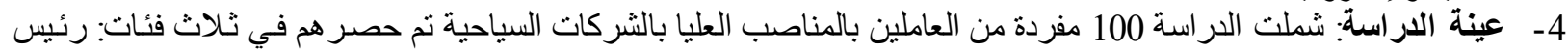

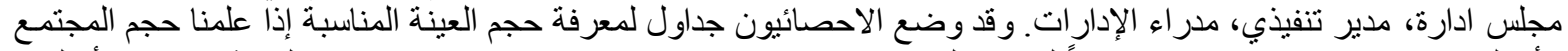

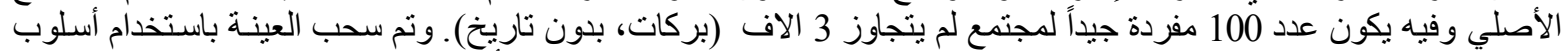
العينة التشو ائية البسيطة. هذا وقد عولجت البيانات المتحصل عليها باستخدام بعض الأساليب الإحصائية.

الار اسة الميدانية وصف العينة:

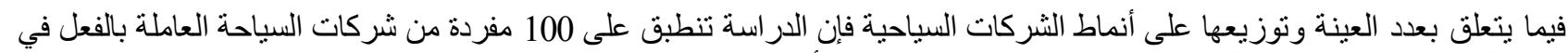

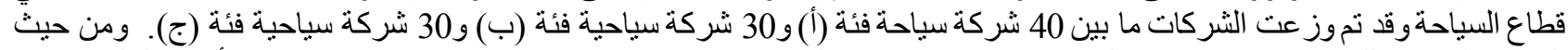
التوزيع الوظيفي للعينة فقد تنو عت مهن المبحوثين ما بين رئيس مجلس إدارة ومدير تنفيذي ومدير إدارة وموظف فئس ما بين الأعداد التالية: رئيس 
مجلس إدارة 6 ومدير تنفيذي 40 ومدير إدارة 54 ـومن حيث نطاق تعامل الثركة مع وزارة السياحة فقد تراوح نطاق تعامل الثركة السياحية

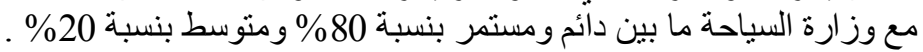

نتائج الدراسة الميدانية:

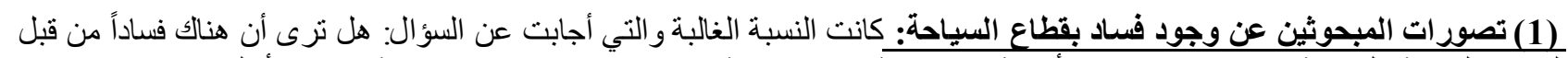

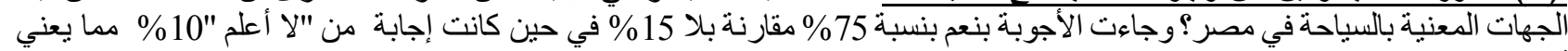
أن معظم الثركات محل الأر اسة تتصور وجاء وجود فساد في القطاع السياحي.

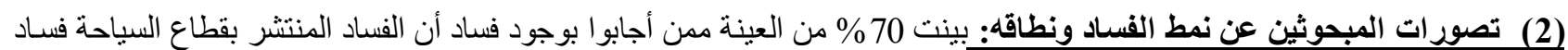

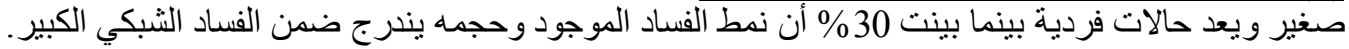

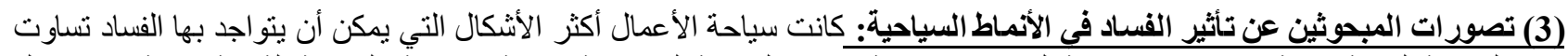

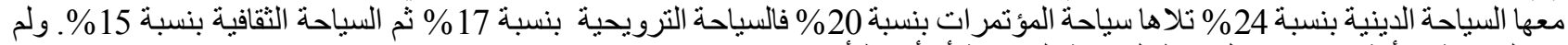
يبد المبحوثون أية دلالات حول نمط السياحة السياسية أو أنماط أخرى.

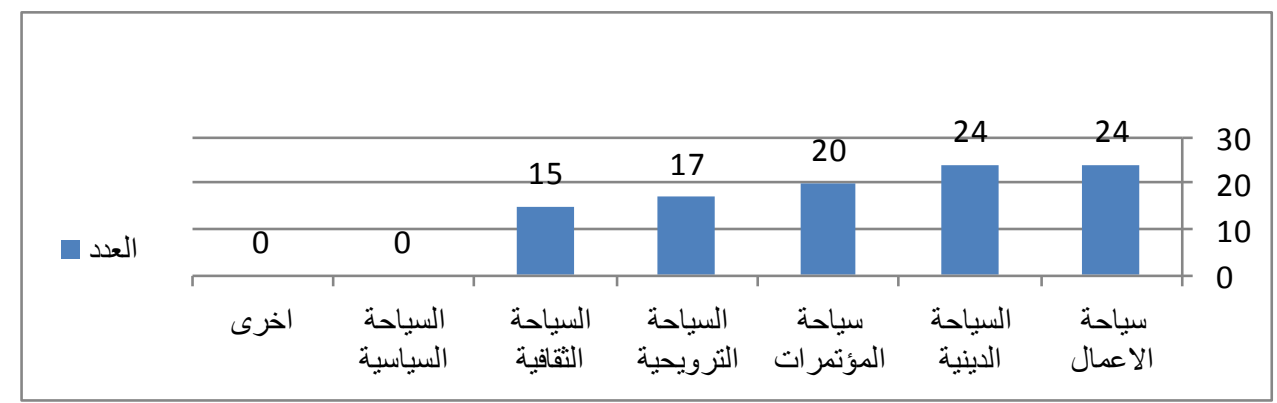

شكل رقم (1) الفساد و الأنماط السياحية

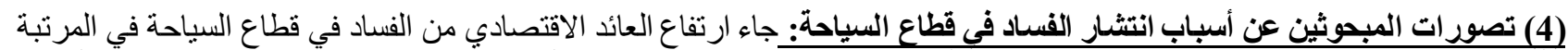

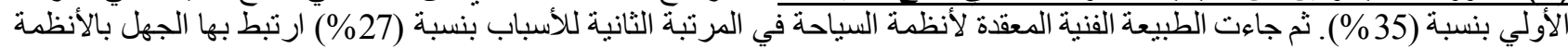

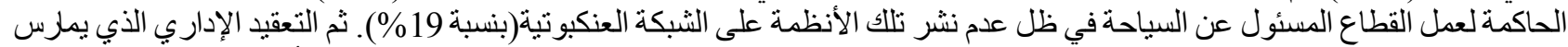

من جانب المسئولين عن إدارة القطاع بنسبة (11\%). وتساوى سببا شكلية المساعلة داخل الوزارة وتراجع نور الأجهزة الرقابية(4)

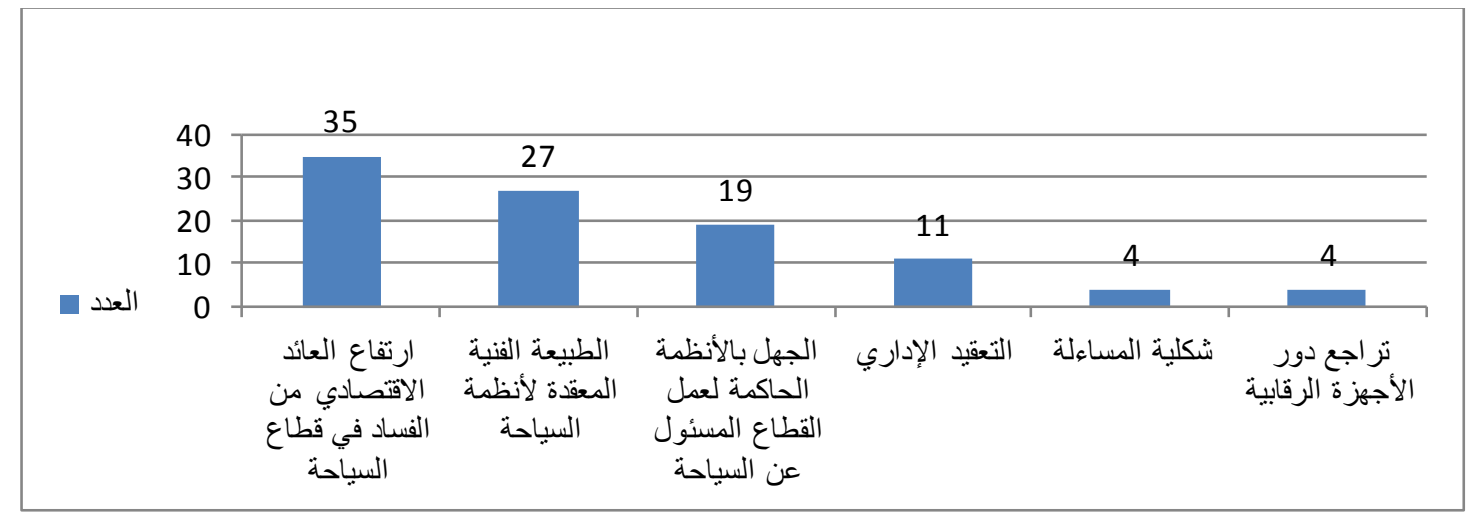

شكل رقم (2) تصورات المبحوثين عن أسباب انتشار الفساد في قطاع السياحة

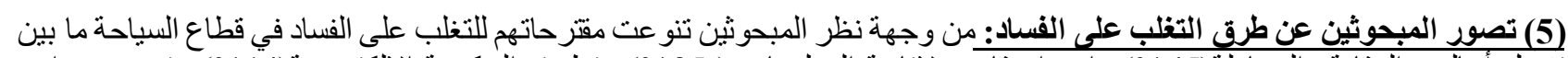

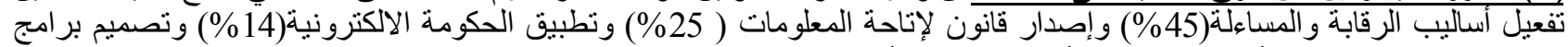
تدريبية للتو عية بالسلوك الأخلاقي(11\%) و أخيرا تحسين الأوضاع المعيشية للعاملين بوزارة السياحة (5\%). 


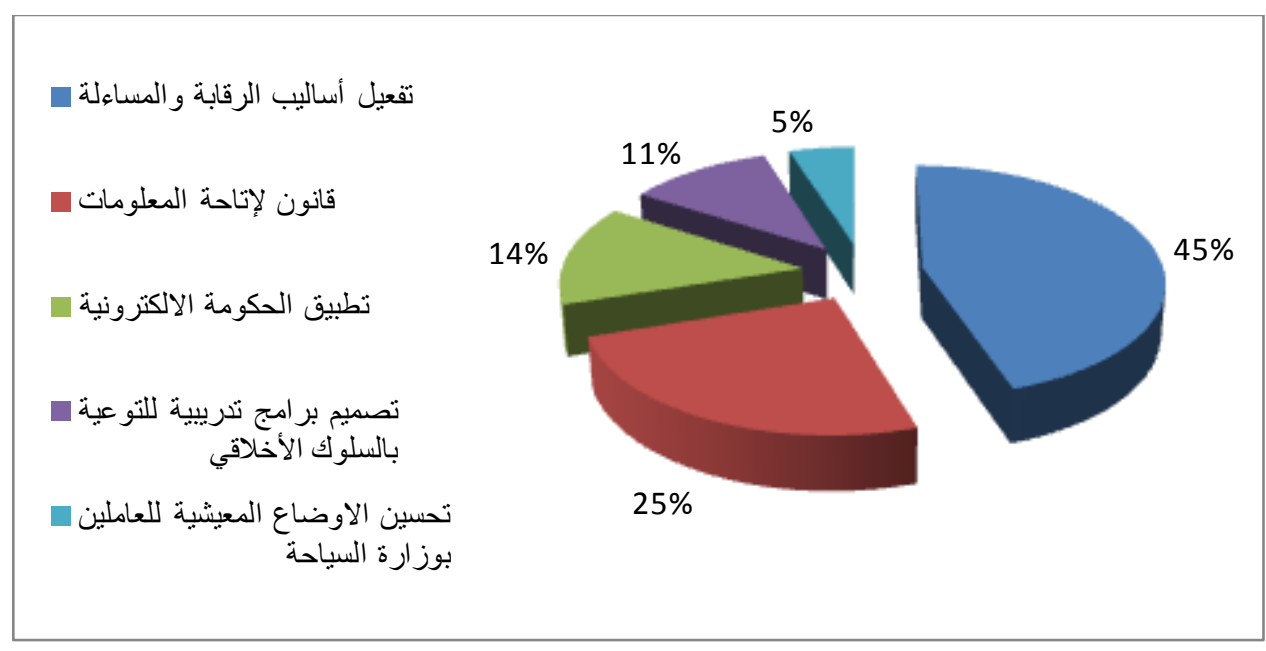

شكل رقم (3) مقترحات التظلب على الفساد السياحي

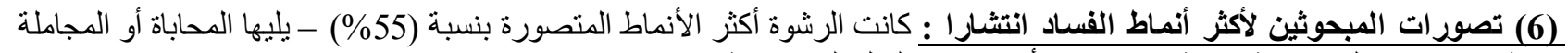

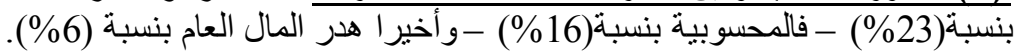

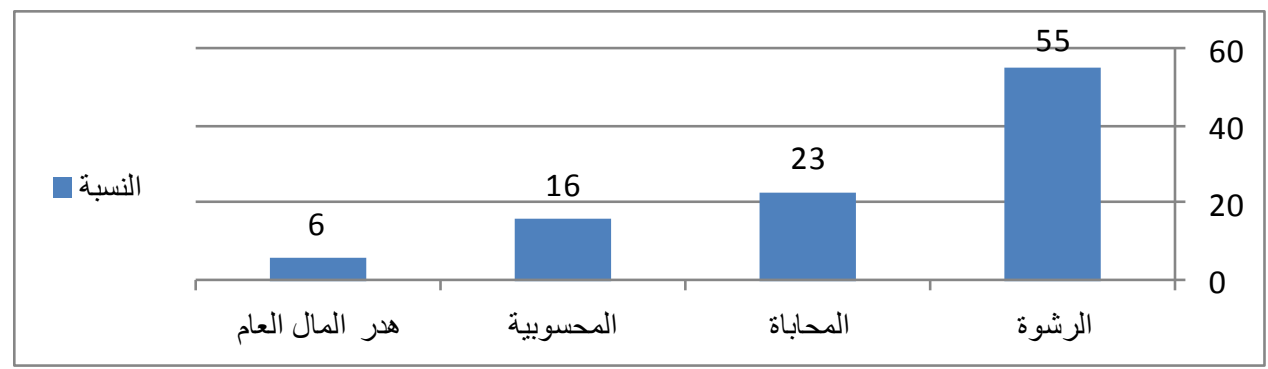

شكل رقم (4) تصورات المبحوثين لانماط الفساد

(7) تصور ات المبحوثين عن تداعيات تأثير الفساد في السياحة.

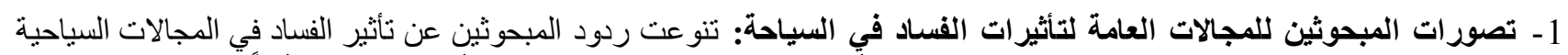

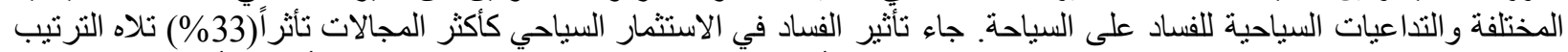

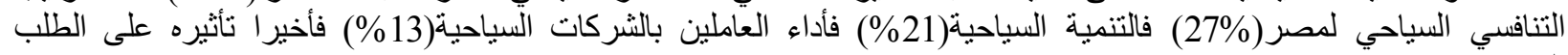
السياحي(\%6).

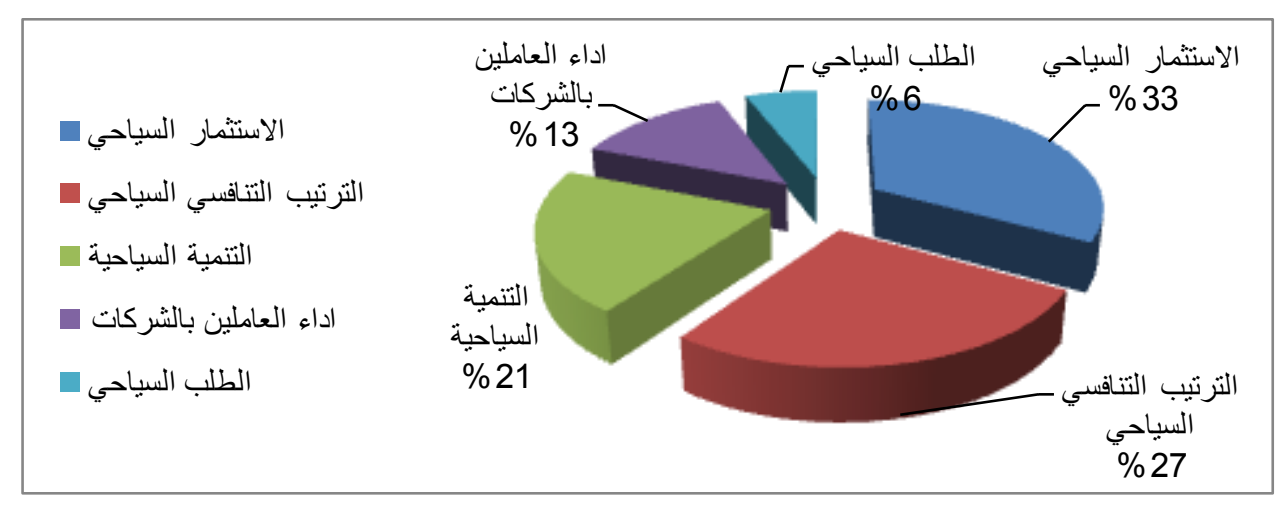

شكل رقم (5) الفساد ومجالات التأثير السياحي

2- تصور ات المبحوثين عن اتجاهات تأثير الفساد في السياحة: استهدف الباحث قياس تصور ات المبات المبحوثين لاتجاهات تأثير الفساد في السياحة

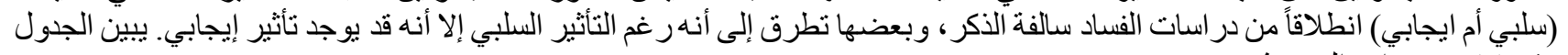
رقم (1) تصورات المبحوثين. 
أثر الفساد الإداري في السياحة: دراسة لتصورات عينة من العاملين بالمناصب العليا بالشركات السياحية

جدول رقم (1) تصورات المبحوثين لاتجاهات تأثير الفساد في السياحة

\begin{tabular}{|c|c|c|c|c|c|c|c|}
\hline \multirow{2}{*}{ الالمعيراف } & \multirow{2}{*}{ الحستوسي | المتبي } & \multicolumn{5}{|c|}{ الاستجابة \% } & \multirow[b]{2}{*}{ العبارة } \\
\hline & & معارض بشدة & معارض & محايد & مو افق & أو افق بشدة & \\
\hline 0.220 & 1.05 & 95 & 5 & 0 & 0 & 0 & 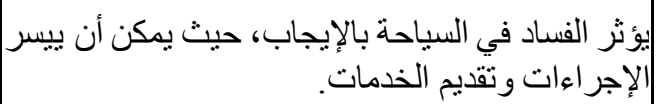 \\
\hline
\end{tabular}

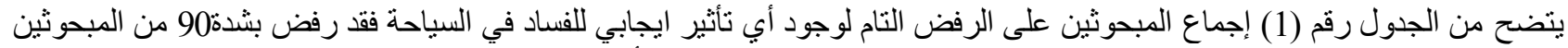

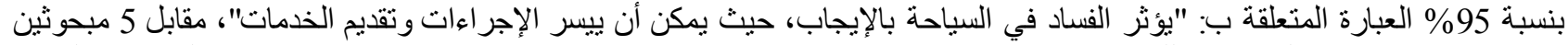
بنسبة 5\% رفض هذه العنبارة العبارة، وذلك بمنوسط حسابي 1.05 و انحر اف معياري

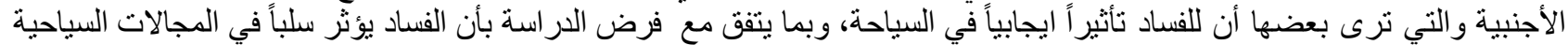

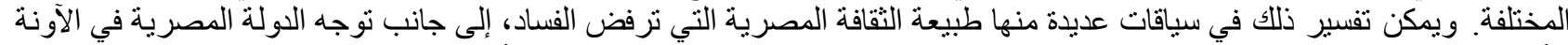

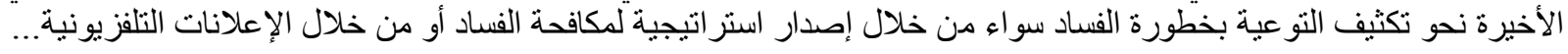

(8)

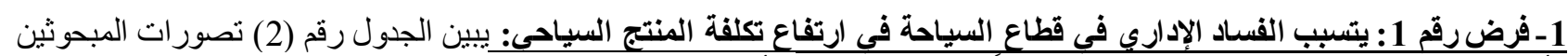

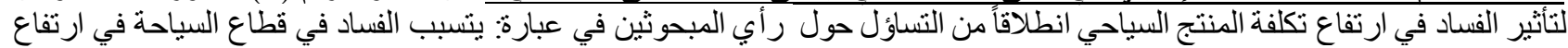
تكلفة المنتج السياحي المقدمة من الثركات السياحية.

جدول رقم (2) تصور ات المبحوثين لتأثير الفساد على تكلفة المنتج السياحي

\begin{tabular}{|c|c|c|c|c|c|c|c|}
\hline \multirow{2}{*}{ الالمعراف } & \multirow{2}{*}{ الحستوسط } & \multicolumn{5}{|c|}{ الاستجابة \% } & \multirow{2}{*}{ 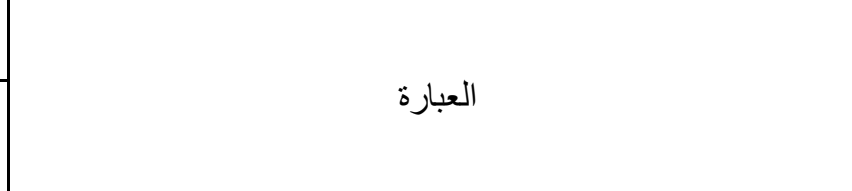 } \\
\hline & & بشدة & 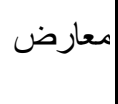 & محايد & مو افق & أو أفق & \\
\hline 0.643 & 4.52 & . & . & 8 & 32 & 60 & ببب الفساد في قطاع السياحة في ارتفاع تكلفة المنتج السياحي المقدمة \\
\hline
\end{tabular}

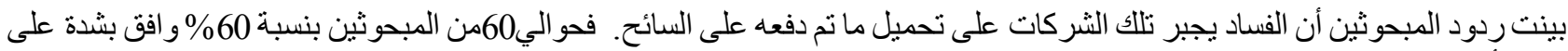

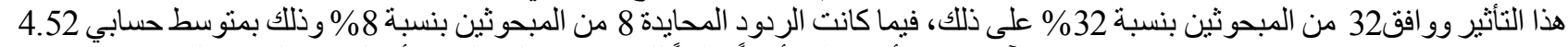

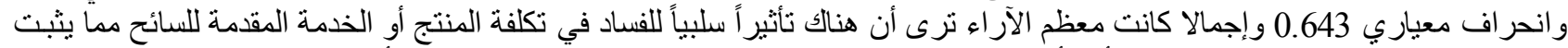

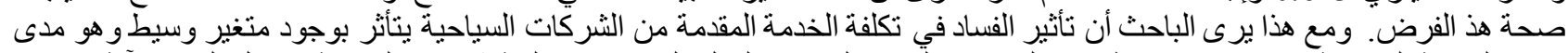

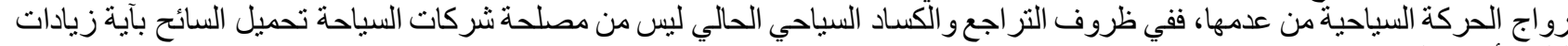

لقلة الأعداد السياحية.

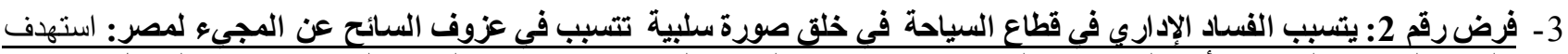

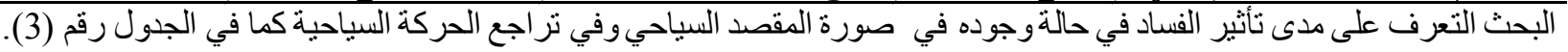


جدول رقم (3) تصور ات المبحوثين لتأثير الفساد في صورة المقصد السياحي

\begin{tabular}{|c|c|c|c|c|c|c|c|}
\hline \multirow{2}{*}{ المعياري افت } & \multirow{2}{*}{ الحستوسطي } & \multicolumn{5}{|c|}{ الاستجابة \% } & \multirow[b]{2}{*}{ 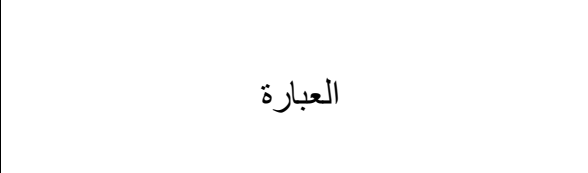 } \\
\hline & & 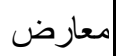 & 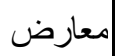 & محايد & 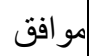 & | أو افق بشدة & \\
\hline 0.000 & 5.000 & 0. & 0 & 0 & 0 & 100 & صبورة سلبية عن مصر. الفساد في قطاع السياحة في خلق| \\
\hline 0.472 & 3.67 & 0 & 0 & 33 & 67 & 0 & برتبطوجود الفساد بوجود مشكلات تهدد السياحة. \\
\hline 0.823 & 2.01 & 33 & 33 & 34 & . & . & فلاد من عدمه. ألسائح يهتم أثناء زيارة مصر بوجود \\
\hline 0.368 & 4.84 & 0 & 0 & 0 & 16 & 84 & 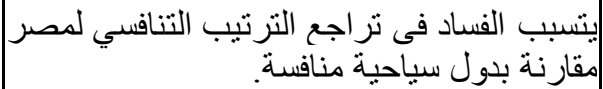 \\
\hline
\end{tabular}

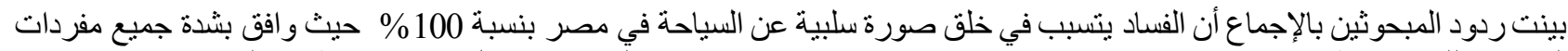

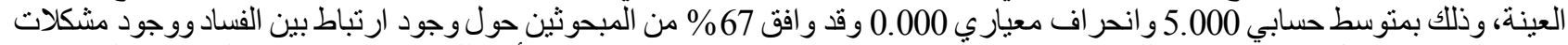

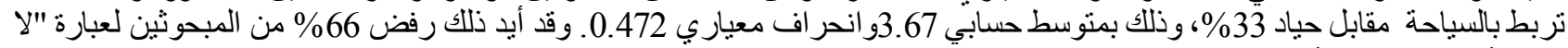

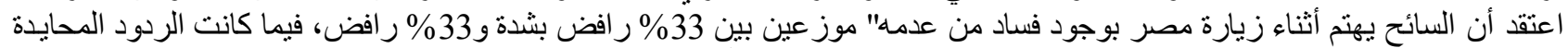

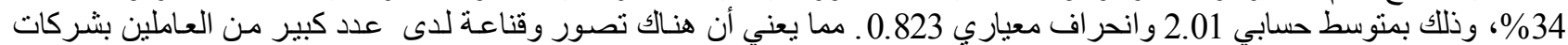

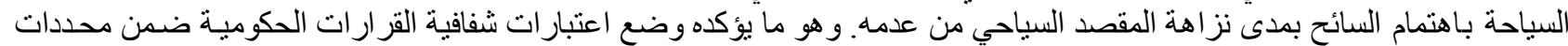

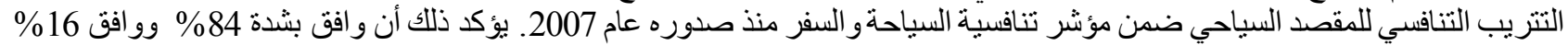
من المبحوثين على أن الفساد يتسبب في تراجع الترتيب التنافسي لمصر سياحيا مقارنة بدول منافسة سياحيا، وذلك بمتوسط حسافي حسابي 4.84 و انحر اف معياري 0.368 من

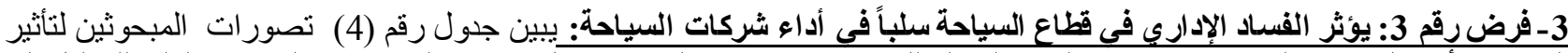

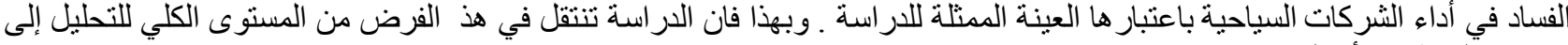
مستوى ألمنظمات أو الثركات.

جدول رقم (4) تصور ات المبحوثين لتأثير الفساد في أداء الثركات السياحية

\begin{tabular}{|c|c|c|c|c|c|c|c|}
\hline \multirow{2}{*}{ المعياري اف } & \multirow{2}{*}{ الحسابي } & \multicolumn{5}{|c|}{ الاستجابة \% } & \multirow[b]{2}{*}{ العبارة } \\
\hline & & معشدة & معارض & محايد & مو افق & أو افق بشدة & \\
\hline 0.461 & 4.700 & 0 . & 0 . & 0 & 30 & 70 & 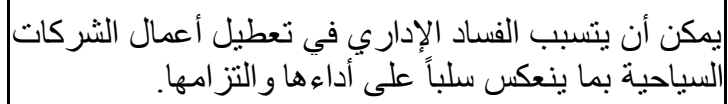 \\
\hline 0.402 & 3.800 & 0 & 0 & 20 & 80 & 0 & |فعالية. الفساد في السياحة عمل الثركات السياحية بكفاءة \\
\hline
\end{tabular}

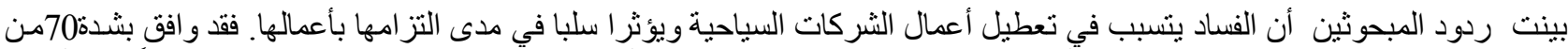

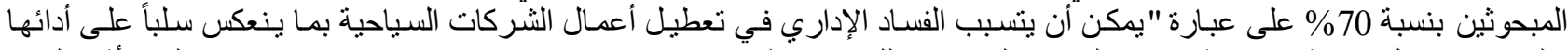

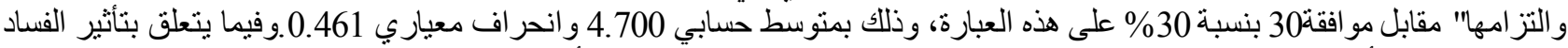

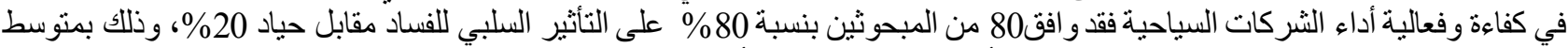

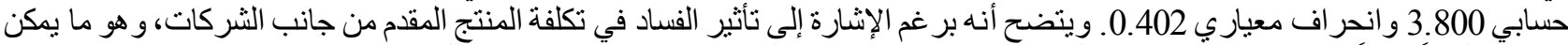

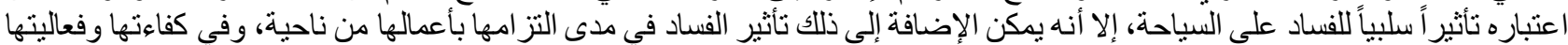
من ناحية أخرى.

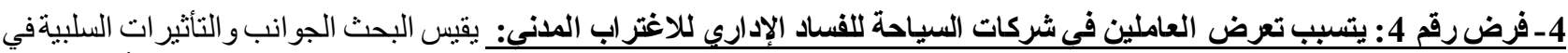

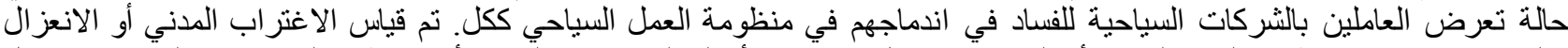
و العزوف عن الانخراط في الحياة المهنية أو العامة من خلال عدد من الأسئلة التي راعي الباحث أن يربطها بالسياحة في النهاية من خلال 
أثر الفساد الإداري في السياحة: دراسة لتصور ات عينة من العاملين بالمناصب العليا بالثركات السياحية

جدول رقم (5) تصورات المبحوثين لتأثير الفساد في الاغتر اب الاجتماعي والمدني

\begin{tabular}{|c|c|c|c|c|c|c|c|}
\hline \multirow{2}{*}{ | - الانحر اف } & \multirow{2}{*}{ الحستبي } & \multicolumn{5}{|c|}{ الاستجابة \% } & \multirow{2}{*}{ 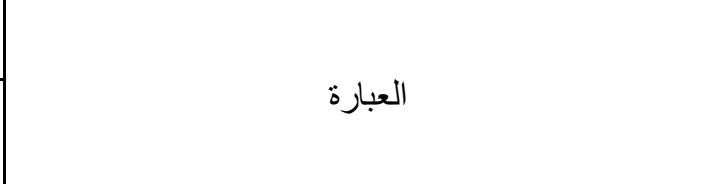 } \\
\hline & & 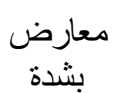 & 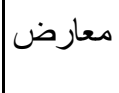 & 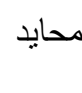 & 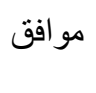 & 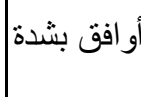 & \\
\hline 0.435 & 4.75 & 0 & 0 & 0 & 25 & 75 & |بالسياحة. بأن التعرض للفساد يضعف تقتي في الجهات المعنيةً \\
\hline 0.000 & 5.00 & 0 & 0 & 0 & 0 & 100 & تيتاثٔر رضت لظائي عناجم عن الفساد. \\
\hline 0.000 & 5.00 & 0 & 0 & 0 & 0 & 100 & القطظاع. ، ينسبب الفساد في هروب المستثمر السياحي من الاستثمار في \\
\hline 0.809 & 4.05 & 0 & 0 & 30 & 35 & 35 & أؤمن بأن التعرض للفساد يخلق حالة من اللامبالاة. \\
\hline 0.338 & 1.13 & 87 & 13 & 0 & 0 & 0 & المنع السلوك ك الفاسدام الحاكمة و المنظمة للفساد في السياحة ر ادعة| \\
\hline
\end{tabular}

و افق بثدة 75 من المبحوثين بنسبة 75\% \% على أن تعرضهم للفساد بمكن أن يضعف ثقته في الجهات المعنبة بالسياحة، فيما وافق25من

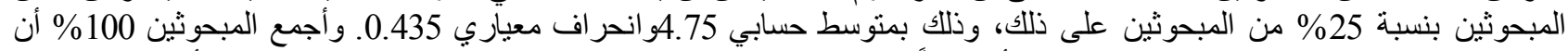

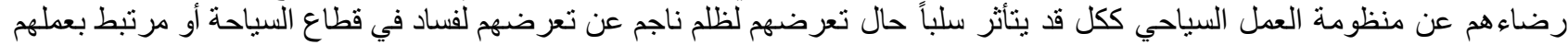

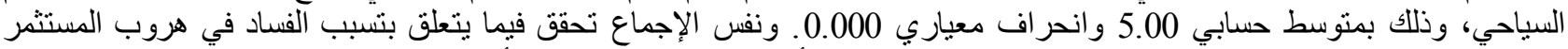

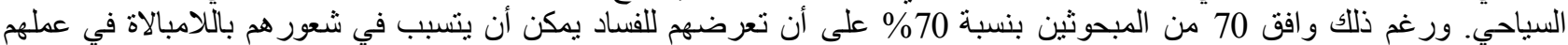

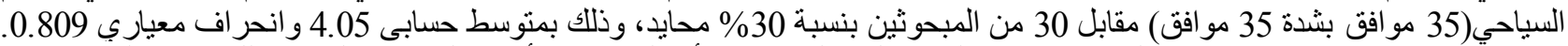

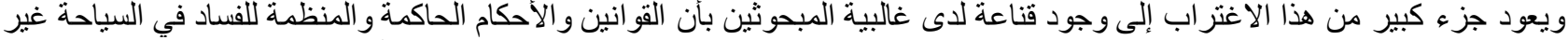

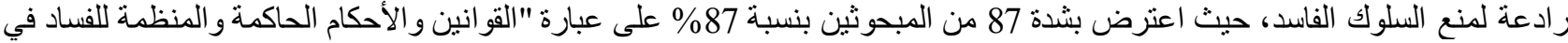

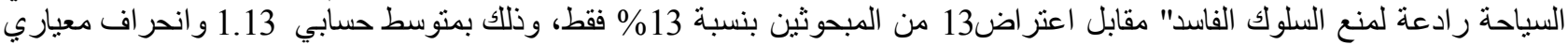

.0 .338

وفيما يلي نتائج التحليل الإحصائي لاختبار صحة الفروض باستخدام معامل ارتباط سبيرمان كما في الجدول التالي( جدول رقم6 )

جدول رقم (6) نتائج معامل ارتباط سبيرمان

\begin{tabular}{|c|c|c|c|c|c|}
\hline شركات اللعاملين في السيت المدني & أداءثير شركات السلبي علي & عزوف السائح & المنتج السياحي تكلفة & \multicolumn{2}{|c|}{ العبارة } \\
\hline 0.611 & 0.589 & 0.556 & 0.632 & معامل الارتباط & \multirow{2}{*}{ قطاع السياحة } \\
\hline 0.000 & 0.000 & 0.000 & 0.000 & المعنوية & \\
\hline
\end{tabular}

يتضح من خلال جلول رقم ( 6 ) أن هناك ارتباطاً بين متغيرات الدراسة، حيث جاءت النتائج علي النحو التالي:

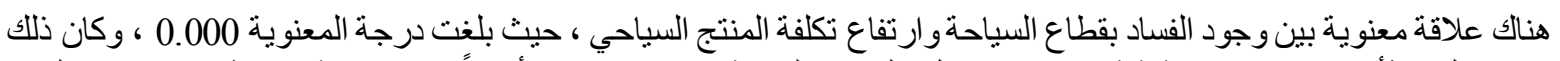

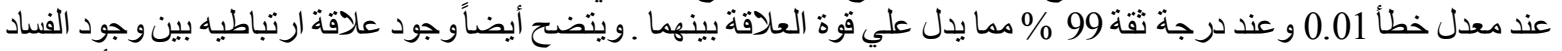

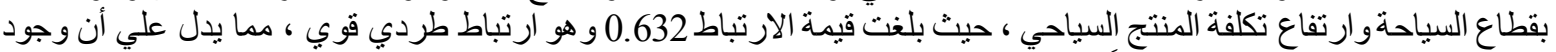

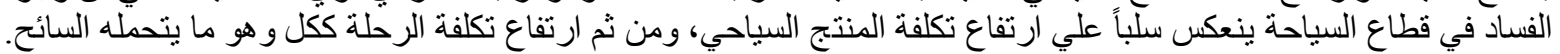

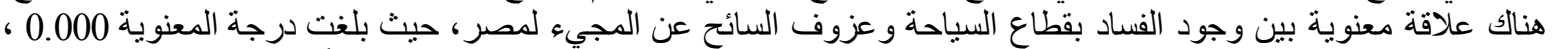

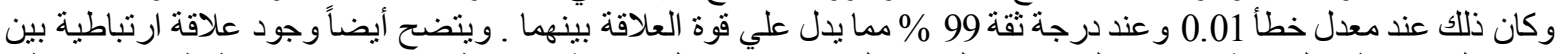
وجود الفساد بقطاع السياحة وعزوف السائح عن المجيء لهصر ، حيث بلغت قيمة الارتباط 0.556 و هو ارتباط طردي منوسط ، 
مما يدل علي أن وجود الفساد في قطاع السياحة ينعكس علي رفض السياح تكرار زيارتهم لمصر بسبب الصورة السيئة للمقصد

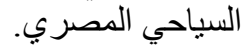

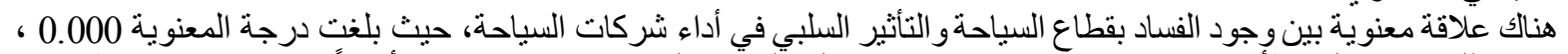

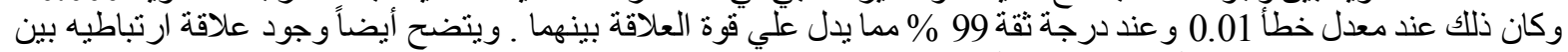

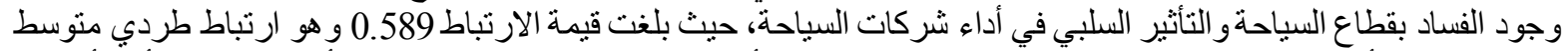

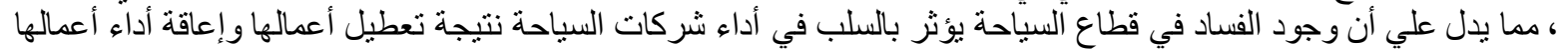
بكفاءة.

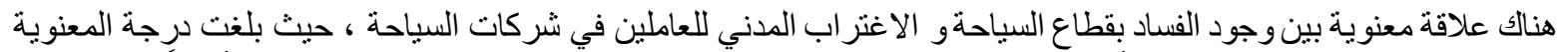

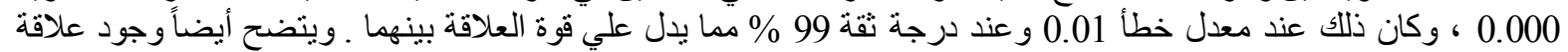

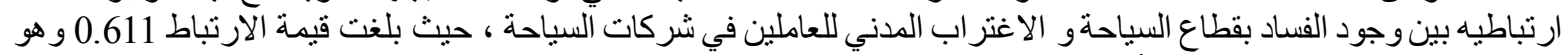

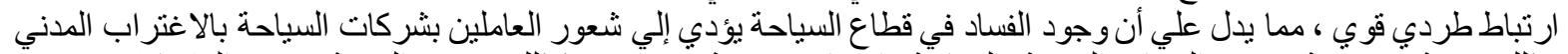

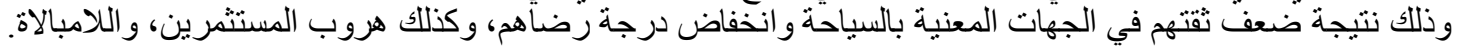

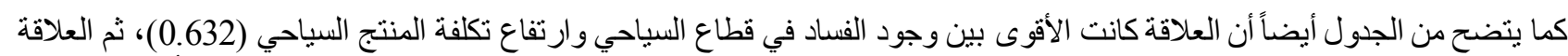

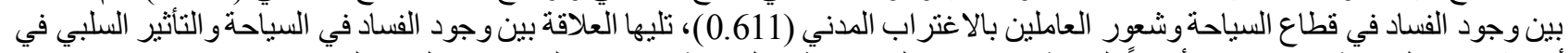

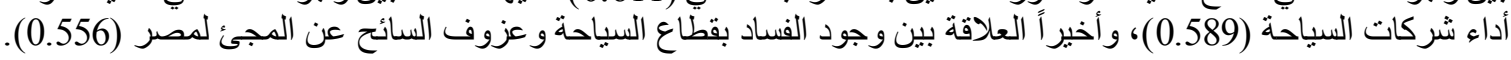

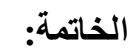

النتائج

نتائج عامة

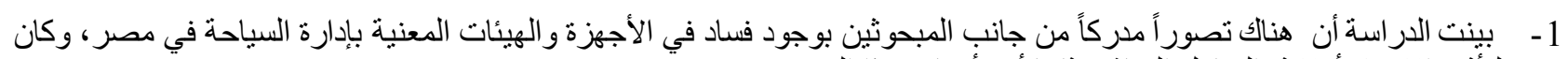

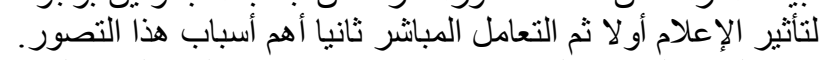

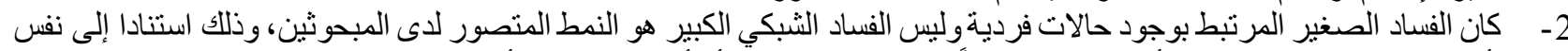

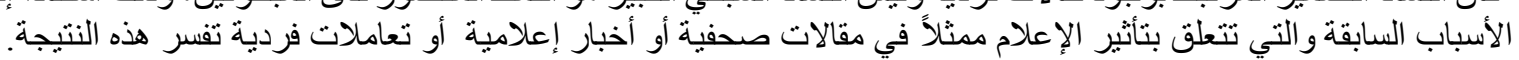

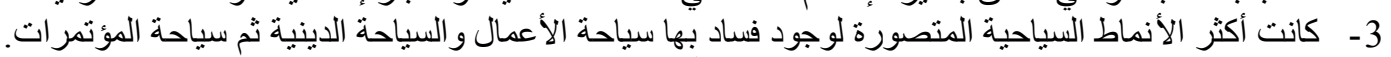

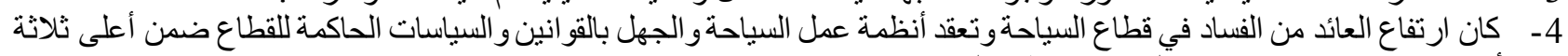

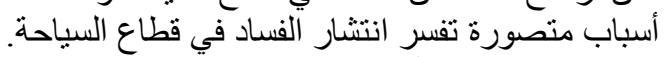

5- الرشوة هي النمط الأكثر انتشار اللفساد في قطاع السياحة ثم المحاباة أو المجاملة وخاصة في مجال التنمية السياحية ثم المحسوبية فهرر

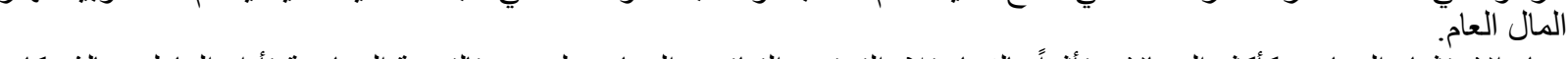

6- جاء الاستثمار السياحي كأكثر المجالات تأثراً بالفساد تلاه الترتيب التنافسي السياحي لمصر فالتنمية السياحية فأداء العاملين بالثركات

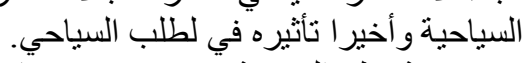

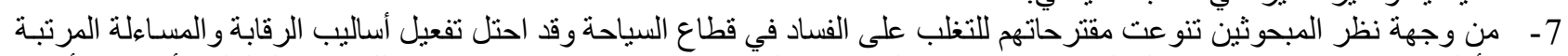

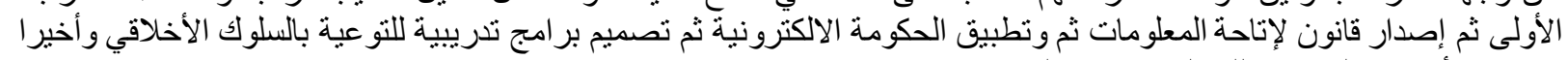

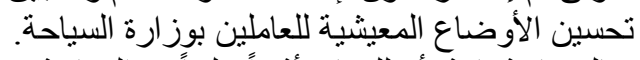

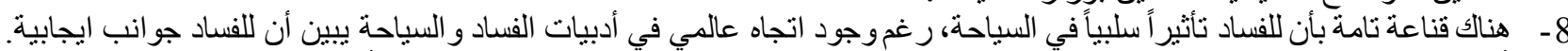

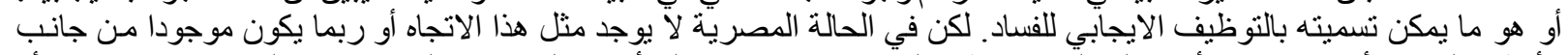

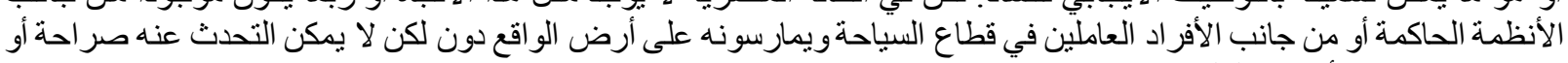
الإفصاح عنه في الأدبيات العلمية.

نتائج تتعلق باختبار صحة الفروض الإحساح في الادبات

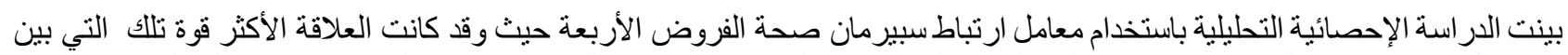

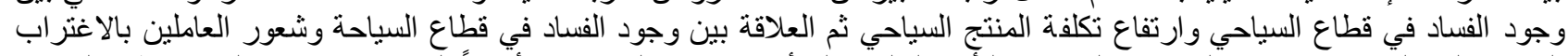

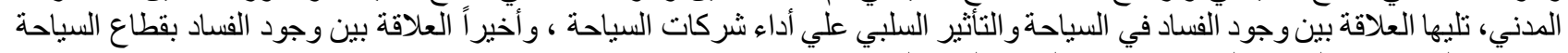

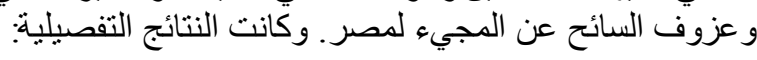

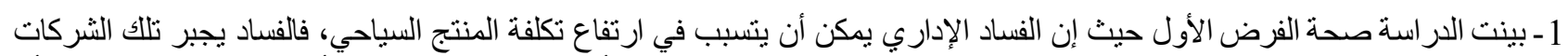

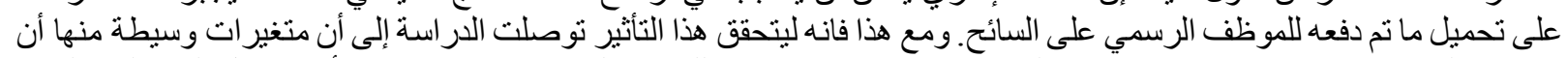

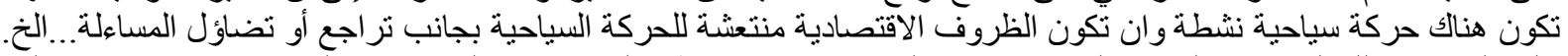

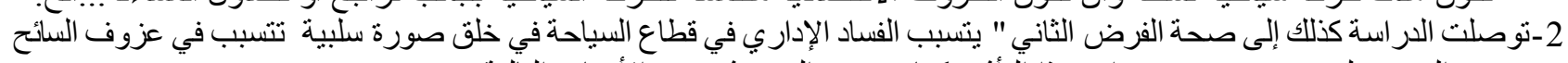

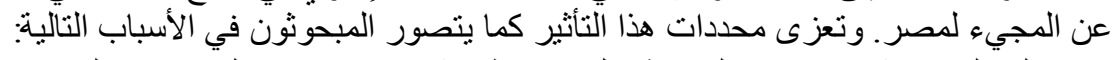

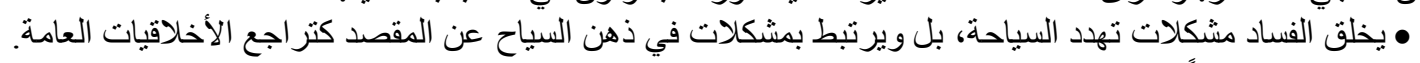

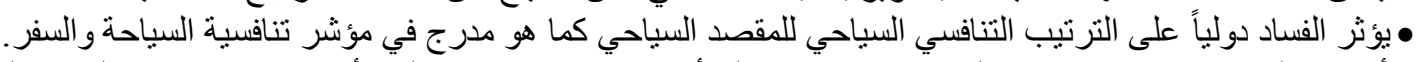

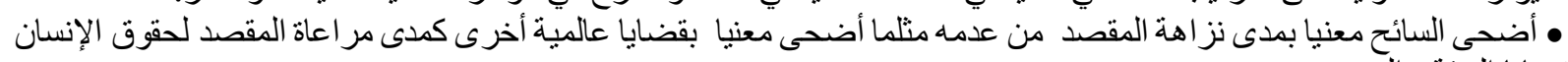

وقضايا البيئة...الخ. الخع. معن.

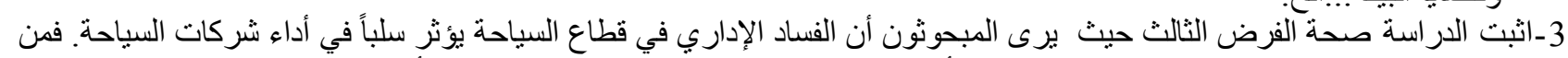

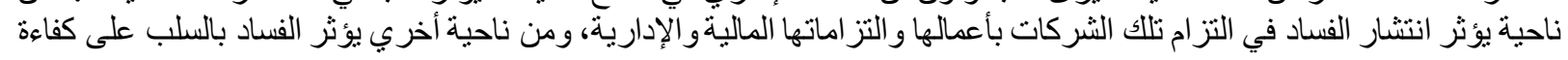




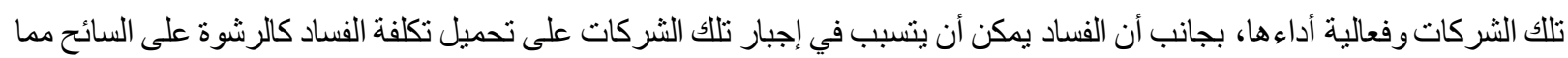

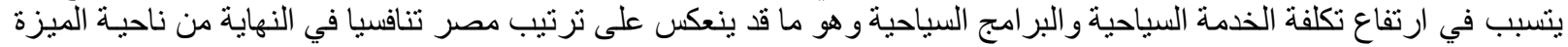

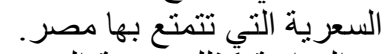

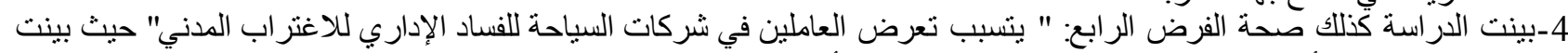

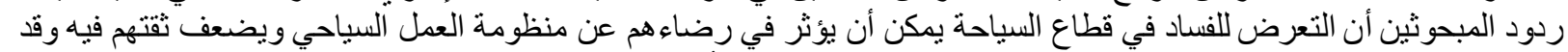

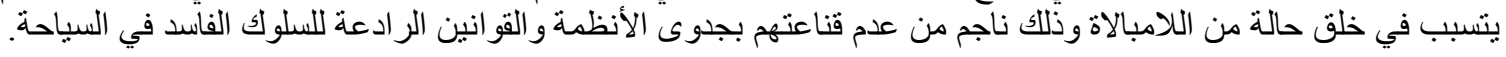

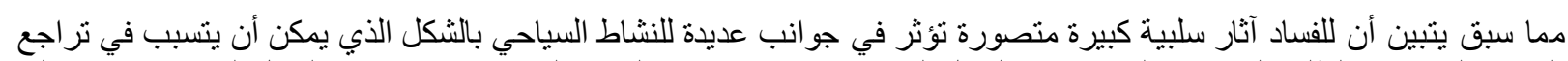

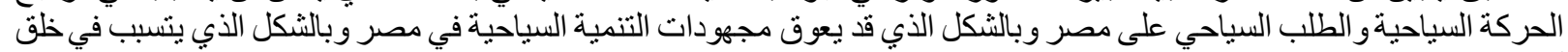

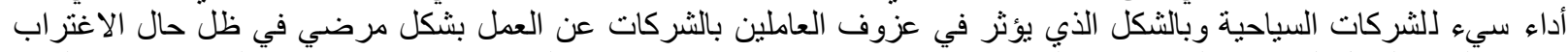

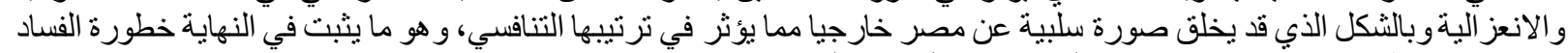

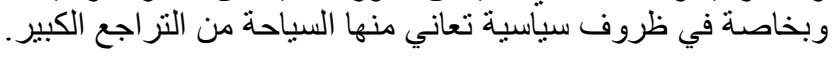

التوصيات:

1- من الأهمية تفعيل أساليب الرقابة والمساءلة وضرورة إصدار قانون لإتاحة المعلومات وتطبيق الحكومة الاكتثرونية وأخير ا تحسين الأوضاع المعيشية للعاملين بوزابل الإرة السياحة.

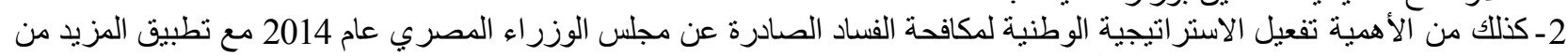

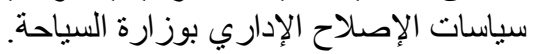

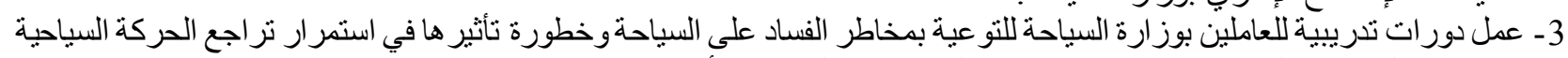

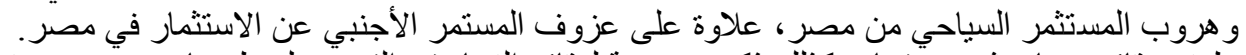

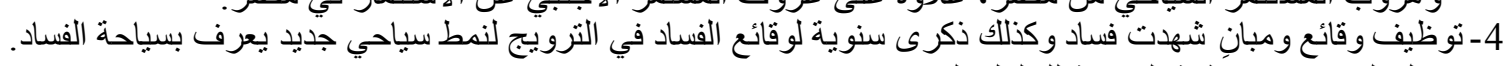

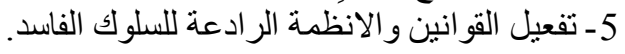

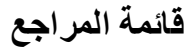 \\ المر اجع باللغة العربية}

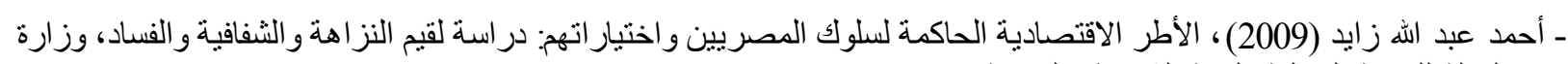
الدولة للتنمية المحلية، لجنة الثفافية و النزا اهذة.

ـ أماني عبد الهادي الجوهري (2004)، الأداء الحكومي و الاغتراب السئة السياسي في مصر: دراسة ميدانية، رسالة ماجستير في العلوم السياسية جامعة القاهرة، كلية الاقتصاد و العلوم السياسية.

- بركات عبد العزيز، مقدمة في مناهج البحث، برنامج التعليم المفتوح، المحاضرة الثالثة(جامعة القاهرة: مركز جامعة القاهرة للتعليم المفتوح، بلون تاريخ).

- حمد مصطفى معبد (2012)، الآثار الاقتصادية للفساد الإداري، الطبعة الأولى، الإسكندرية: دار الفكر الجامعي.

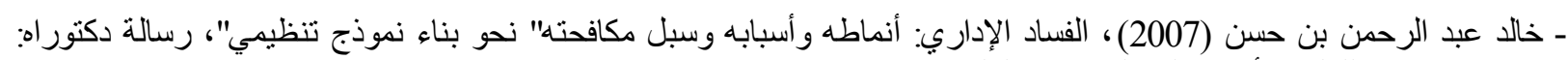
جامعة نايف للعلوم الأمنية كلية الدر اسات العليا.

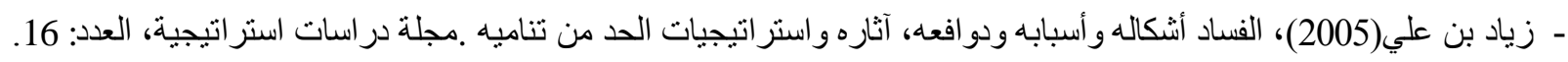
ـ السيد علي شتا (1999)، الفساد الإداري ومجتمع المستقبل، الإسكندرية: مطبعة الإشعاع الفنبة.

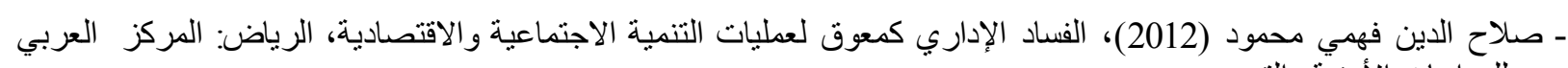
للار اسات الأمنية والتدريب.

ـ عماد الدين إسماعيل، ظاهرة الفساد الإداري في الأجهزة الحكومية بالتركيز علي الرشوة: دراسة تطبيقية، جامعة القاهرة: كلية

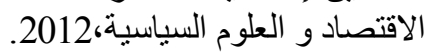

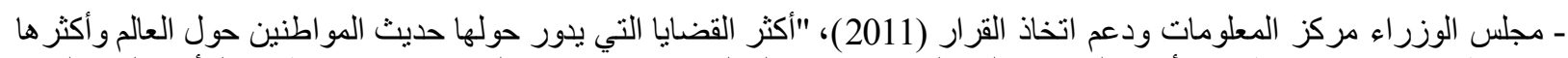

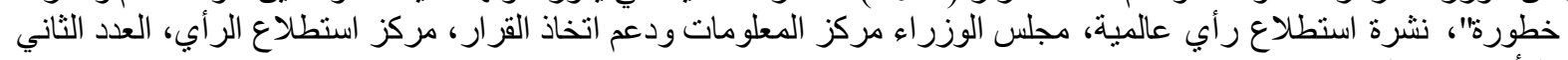
و الأربعين - يناير.

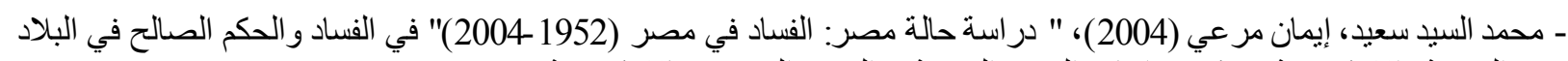

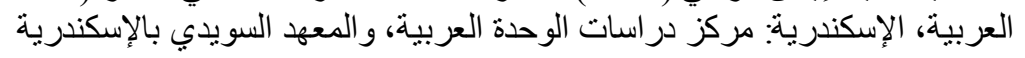

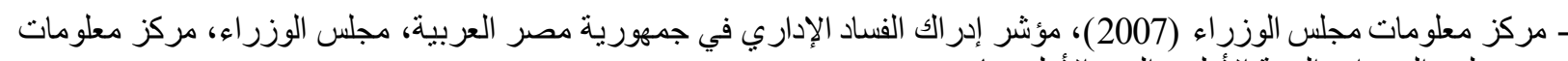
مجلس الوزراء. السنة الأولى، العدد الأول، مايو. ـ ـ المعهر العربي للتخطيط بالكويت (2008)، مؤشرات قياس الفساد الإداري، جسر التنمية، العدد السبعون، السنة السابعة. 
- نور أنور عانثور الدلو (2015)، دور التحقيق الصحفي في معالجة قضايا الفساد بالصحافة الفلسطينية، رسالة ماجستير، الجامعة الإسلامية بغزة، كلية الآداب.

ـ وزارة الحولة للتنمية الإدارية، لجنة الثفافية والنزاهة(2008)، التقرير الثاني: أولويات العمل والياته، القاهرة: وزارة التنمية الإدارية، أغسطس.

- يوسف خليل اليوسف (2002)، الفساد المالي والإداري ، الأسباب والنتائج وطرق العلاج، بحث منشور في مجلة العلوم الاجتماعية ، المجلد ، 30العدد2، الإمارات: قسم الاقتصاد.

باللغة الانجليزية

Anatusi, T. C.; and Nnabuko, J.O.;(2012), "Corruption And Tourism: Restructuring Nigeria's Image For Development Using Public Relations Strategies", Arabian Journal Of Business And Management Review, Vol. 2, No.4; Dec.

Assaf, A.G.; and Josiassen;(2012), A. "Identifying and Ranking the Determinants of Tourism Performance: A Global Investigation", Journal of Travel Research, 51(4).

Boris B.; (2005), "Corruption: Concepts, Causes, and Consequences". Economic Reform, Center for International Private Expertise, March 21.

Center for democracy and governance(1991), A hand book on fighting corruption, Washington D.C., technical publication series.

Corruption and Alienation, Paper to be presented at ECPR Joint Sessions ToiniL øvseth (2001), Grenoble, Panel 16 "Corruption, Scandal and the Contestation of Governance in Europe.

Das, J.; and Dirienzo; (2010), C. "Tourism competitiveness and corruption: A cross-country analysis". Tourism Economics, 16(3).

Duffy, R .; and Shadow P.; (2000)," Ecotourism development, corruption and state politics in Belize". Third World Quarterly, 21(3).

Espinal, R. and Hartlyn J.; (2006), "Performance Still Matters Explaining Trust in Government in the Dominican Republic," Comparative Political Studies 39, 2 March, 200-23 .

Fredenrick S.; and Petter L.; (1997), " The Role of Public Administration in Fighting Corruption", International Journal of Public Management, vol. 10, no. 5.

Gallego M. S.; Jaume R., N. and Johan F. ;(2016) "The Effects Of Terrorism, Crime And Corruption On Tourism", Ersa Working Paper 595, South Africa, April.

Henderson J.C.;( 2003),"The Politics of Tourism in Myanmar". Current Issues in Tourism 6(2).

Huntington, S.P.;(1989), "Modernization and Corruption," in Arnold J. Heidenheimer, Michael Johnston, and Victor T. Levine, eds., Political Corruption A Handbook (New Brunswick: Transaction Publishers.

Janez M.; Tina K.; and Bojan D.;(2015), "The Impact of Corruption and Organized Crime on the Development of Sustainable Tourism", ARSTVOSLOVJE, Journal of Criminal Justice and Security, no. 2.

Khan M. M.;(2016), " Political and Administrative Corruption: Concepts, Comparative Experience, and Bangladesh case, Asian Affairs

Kiltgaard R.; (1998), "International cooperation against corruption”, IMF/World Bank Finance and Development, 35.

Lau T.; and Hazari B.; (2011), "Corruption and tourism". In Tourism, Trade and Welfare: Theoretical and Empirical Issues, Hazari BR, Hauppauge RH (eds). Nova Publishers: New York.

Manuel V.; G. R, and Cecilia L.; (2011)," Consequences of corruption: study of political attitudes in Spain", 7th Transatlantic Dialogue on Strategic Management of Public Organizations Rutgers University, Newark, New Jersey, June. 
Michael J.; Schneider S. and Kpundeh J.; (2002), Building A Clean Machine: Anti-Corruption Coalitions and Sustainable Reform, Washington: The World Bank.

Paul S.; 2003), The Impact of Corruption on Human Development in The Arab World: A Concept Paper', The Lebanese Transparency Association, and UNDP, April.

Propawe, M.;( 2015), "A panel data analysis of the effect of corruption on tourism", Applied Economics, Vol. 47(3).

Saha S. and Yap, G. ;(2015), "Corruption and Tourism: An Empirical Investigation in a Non-linear Framework", International Journal of Tourism Research, Int. J. Tourism Res., 17.

Susan R. A.; (2001), "Trust, Honesty, and Corruption: Theories and Survey Evidence from Post-Socialist Societies, Toward A Research Agenda for a Project of The Collegium Budapest" Prepared for The Workshop on Honesty and Trust in Post-Socialist Societies at Collegium Budapest, may 25-26.

Tosun, C. and Timothy, D.;( 2001), "Shortcomings in planning approaches to tourism development in developing countries: The case of Turkey", International Journal of Contemporary Hospitality Management, 13(7).

Yap, G. and Saha S.;(2013), "Do Political Instability, Terrorism, and Corruption Have Deterring Effects On Tourism Development Even In The Presence Of Unesco Heritage? A Cross-Country Panel Estimate", Tourism Analysis, Vol. 18.

\title{
The Impact of Administrative Corruption on Tourism: A Study of The Perception of the officials of Tourist Companies.
}

\section{Ahmed Mahrous Khodair}

\begin{abstract}
This study tackles a research problem based on that administrative corruption negatively affects the tourism economy in Egypt, as corruption is deemed as neglected factor that can hinder tourism development. Thus, the main question the study tries to answer: what are the perceptions of the officials of tourist companies regarding the impact of corruption on tourism in Egypt? To answer this question the study depends basically on a methodology of questionnaire on an intended random sample of 100 respondents of the three types of tourist companies in Egypt: A, B, and C. the study concludes that there is a perception among the respondents of the negative impact of corruption on tourism, especially business and recreational tourism, which, in turn, causes a regression in both tourist demand and investment.
\end{abstract}

Key words: Administrative Corruption - Tourism - Types of Corruption- Tourist Companies. 